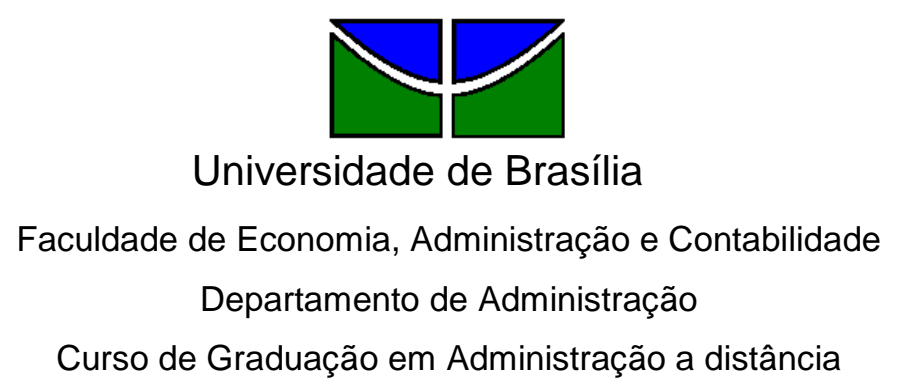

PEDRO MARCOS FRAGA SILVA

\title{
LOGÍSTICA REVERSA COMO FERRAMENTA PARA DIMINUIÇÃO DOS IMPACTOS AMBIENTAIS: O recondicionamento de carcaças dos cartuchos usados de toner
}

Brasília - DF

Ano 2010 


\section{PEDRO MARCOS FRAGA SILVA}

\section{LOGÍSTICA REVERSA COMO FERRAMENTA PARA DIMINUIÇÃO DOS IMPACTOS AMBIENTAIS: 0 recondicionamento de carcaças dos cartuchos usados de toner}

Monografia apresentada a Universidade de Brasília (UnB) como requisito parcial para obtenção do grau de Bacharel em Administração.

Professor Orientador: Prof. Msc Olinda Maria Gomes Lesses

Brasília - DF

Ano 2010 
Silva, Pedro Marcos Fraga.

Logística Reversa como Ferramenta para diminuição dos Impactos Ambientais: o recondicionamento de carcaças dos cartuchos usados de toner / Pedro Marcos Fraga Silva. - Brasília, 2010. $67 \mathrm{f}$. : il.

Monografia (bacharelado) - Universidade de Brasília, Departamento de Administração - EaD, 2010.

Orientador: Prof. Msc Olinda Maria Gomes Lesses, Departamento de Administração.

1. Logística Reversa. 2. Vantagens Econômico-financeiras. 3. Meio Ambiente. 
PEDRO MARCOS FRAGA SILVA

\section{LOGÍSTICA REVERSA COMO FERRAMENTA PARA DIMINUIÇÃO DOS IMPACTOS AMBIENTAIS: 0 recondicionamento de carcaças dos cartuchos usados de toner}
A Comissão Examinadora, abaixo identificada, aprova o Trabalho de Conclusão do Curso de Administração da Universidade de Brasília do aluno

\section{Pedro Marcos Fraga Silva}

Prof. Msc. Olinda Maria Gomes Lesses Professor-Orientador 
Às minhas queridas filhas Camila e Daniela e adorada esposa Márcia, pela paciência e compreensão dos momentos em que precisei dedicar-me exclusivamente aos estudos. 


\section{AGRADECIMENTOS}

Agradeço a Deus, pela minha existência, inspiração e força para me dedicar a este curso de graduação em Administração a distância.

A orientadora, Prof. Msc. Olinda Maria Gomes Lesses, que soube exercer a difícil missão com muita tranquilidade e sabedoria.

A todos os professores e tutores do curso de Administração a distância, pela paciência e dedicação de orientarem alunos adultos, com idades bem acima da média.

Aos colaboradores da Tecno Toner, Evandro Fontana, Eduardo, Rodrigo e José Carlos, pela presteza, dedicação e tempestividade nas informações prestadas.

A todos os colegas da turma, pelos momentos descontraídos e felizes que passamos juntos, os quais ajudaram a superar a tensão e o cansaço dos nove semestres de duração do curso. 
Fala-se tanto em deixar um planeta melhor para nossos filhos... Mas será que vamos deixar filhos melhores para nosso planeta? 


\section{RESUMO}

Devido às constantes mudanças ambientais que despertaram a sensibilidade ecológica e a preocupação cada vez maior da sociedade em alcançar um desenvolvimento sustentável, foram criadas nos últimos anos, por autoridades governamentais, legislações e normas relacionadas à conservação e proteção ao meio ambiente. Dessa forma, para cumprimento dessas exigências legais e para atendimento das expectativas cada vez maiores de consumidores no que diz respeito a políticas de sustentabilidade e proteção ao meio ambiente, e assim, apresentarem uma vantagem competitiva em relação ao mercado, as organizações estão desenvolvendo seus sistemas logísticos tradicionais, ampliando-os com a criação de um novo fluxo logístico, o fluxo inverso. Buscou-se apresentar uma ferramenta gerencial, a logística reversa, que torna possível obter vantagens econômico-financeiras e, ao mesmo tempo, diminuir os danos causados ao meio ambiente. O tipo de pesquisa adotado neste trabalho é descritiva, de caráter bibliográfico e documental, baseado na coleta de informações constantes em livros, artigos publicados na internet, revistas eletrônicas e documentos fornecidos por instituições privadas. Descreveu-se um processo de logística reversa realizado na empresa Tecno Toner Cartuchos para Impressoras, organização brasileira fundada em 1990 que atua na área de remanufatura e comércio de cartuchos, com certificações de gestão de qualidade e respeito ao meio ambiente. Neste estudo apresentou-se uma organização que trabalha em harmonia com a sociedade e o meio ambiente, realizando adequadamente a destinação final de seus resíduos industriais. Constatou-se ainda que a empresa, por meio de seus programas sociais e de reciclagem, promove e contribui com o bem estar da comunidade. Apontou-se neste estudo de caso os benefícios gerados ao meio ambiente, como a diminuição do desperdício e a economia de energia em virtude da reutilização das carcaças de toner, e identificou-se ganhos econômicos, com a comercialização de produtos de alta qualidade e de baixo custo de aquisição. Torna-se, assim, com a apresentação do presente trabalho, uma realidade a redução dos impactos ambientais e a obtenção de vantagem econômico-financeira com a adoção da logística reversa pelas organizações.

Palavras-chave: Logística Reversa. Vantagens Econômico-financeiras. Meio Ambiente. 


\section{LISTA DE ILUSTRAÇÕES}

Figura 1 - Atividades mais comuns do processo logístico inverso.........................24

Figura 2 - Fluxo de operações e logística.................................................29

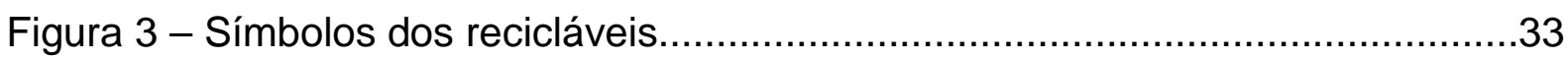

Gráfico 1 - Preços dos cartuchos recondicionados X originais.............................39

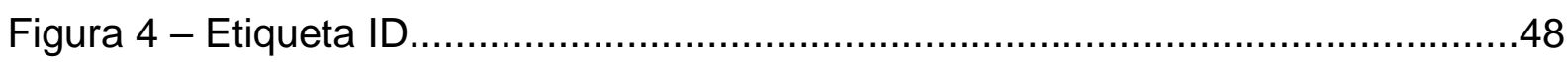

Figura 5 - Ilustração dos seis passos da impressão a laser...............................52

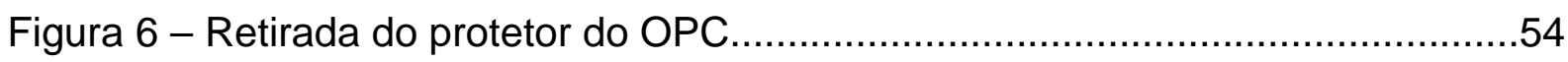

Figuras 7, 8 e 9 - Sequência de retirada do pino do lado esquerdo.......................54

Figuras 10, 11, 12 e 13 - Sequência de retirada do pino do lado direito..................55

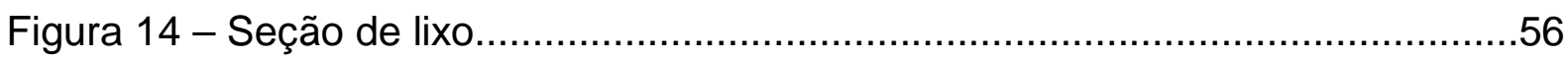

Figuras 15 e 16 - Retirada do pino de aterramento do OPC.................................56

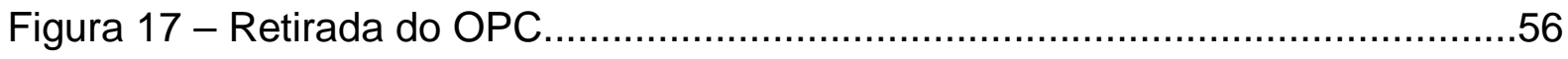

Figura 18 - Detalhe do limitador de curso do OPC .........................................57

Figura 19 - Detalhe da nova engrenagem do OPC ..........................................57

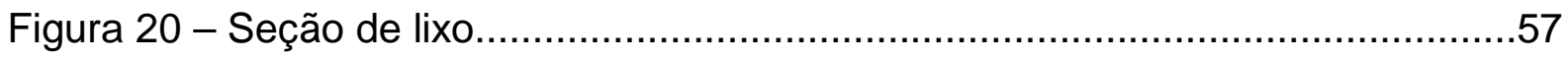

Figura 21 - Inspeção da lâmina de recuperação............................................58

Figura 22 - Lubrificações na seção de lixo................................................58

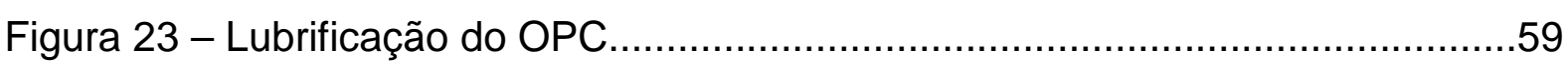

Figuras 24 e 25 - Lateral rebitada do contato do magnético e a retirada do rebite...59

Figuras 26, 27 e 28 - Sequência de furos dos rebites da lateral..........................60

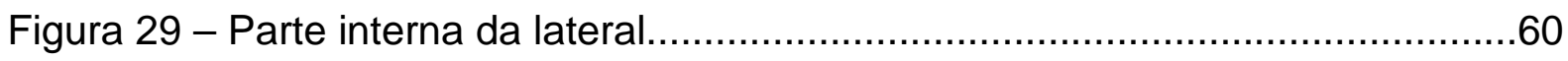

Figura 30 - Retirada do magnético ......................................................61

Figura 31 - Retirada da dosadora.......................................................61

Figura 32 - Detalhe dos limpadores do magnético.......................................62

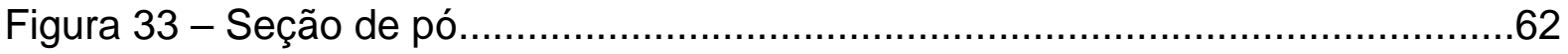




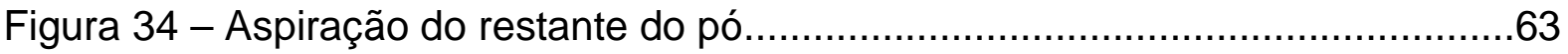

Figura 35 - Lubrificação do contato do magnético.............................................63

Figura 36 - Detalhe dos parafusos já instalados na lateral..................................64

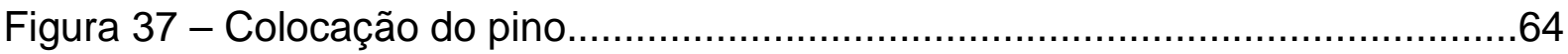

Figura 38 - Posicionando a mola do obturador............................................65

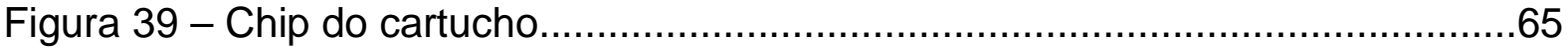




\section{LISTA DE QUADROS E TABELAS}

Quadro 1 - Sinopse da evolução dos sistemas logísticos.................................17

Quadro 2 - Resumo de opções de recuperação de produtos..............................31

Quadro 3 - Resumo do processo de remanufatura dos cartuchos Tecno Toner......38 


\section{SUMÁRIO}

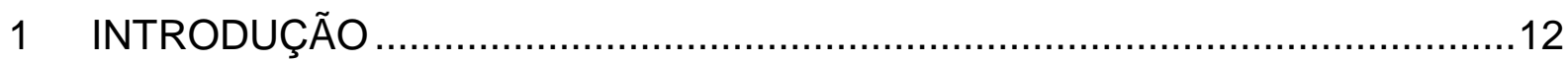

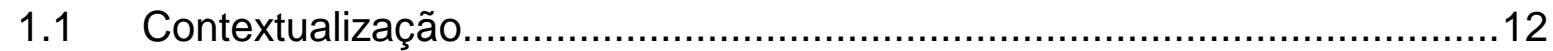

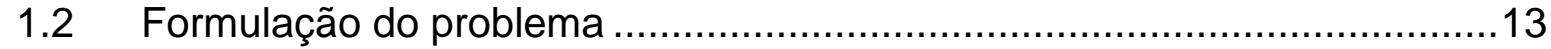

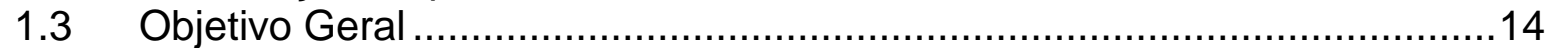

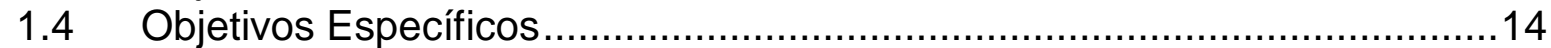

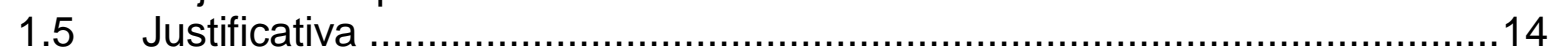

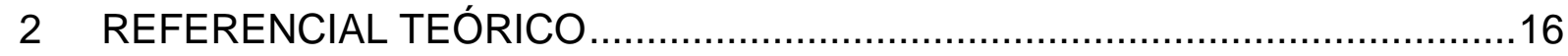

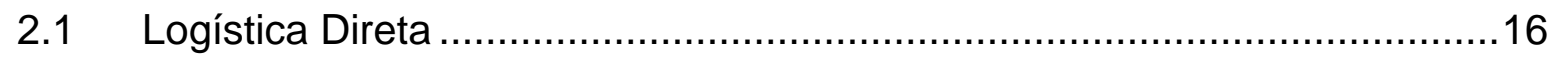

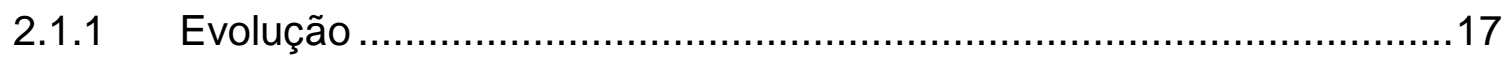

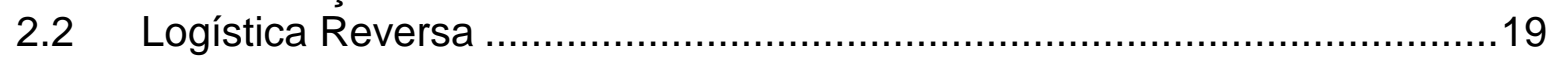

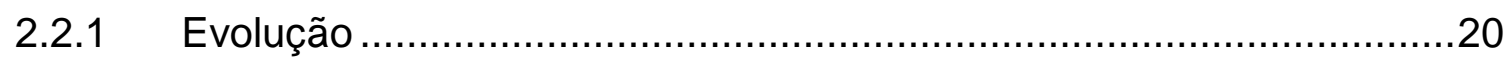

2.2.2 A Questão Ambiental e os Aspectos Econômico-financeiros ...............21

2.2.3 Fluxos Logísticos e Fluxo Inverso ..................................................23

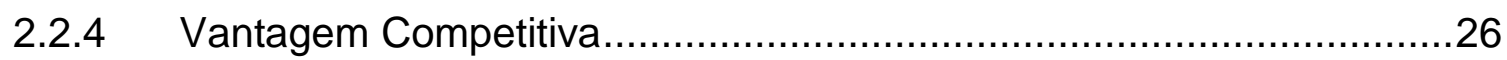

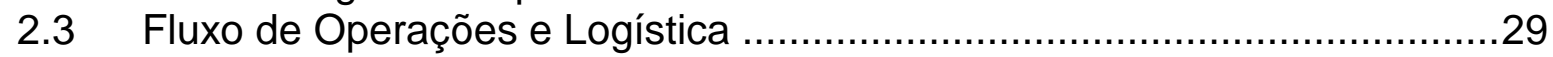

2.4 Administração da Recuperação de Produtos..........................................30

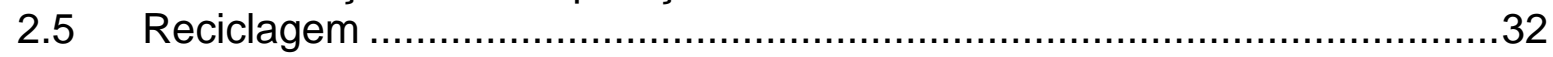

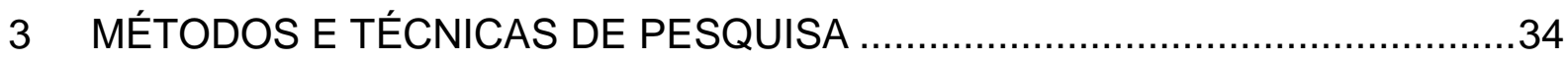

3.1 Caracterização da Organização Objeto de Estudo .....................................34

3.2 Caracterização do Tipo e Instrumento de Pesquisa..................................35

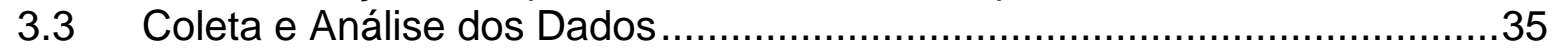

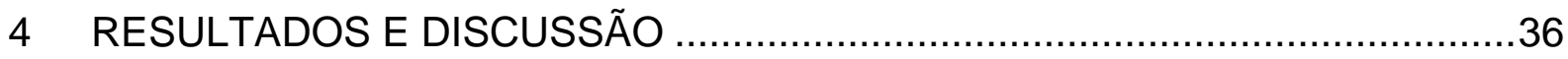

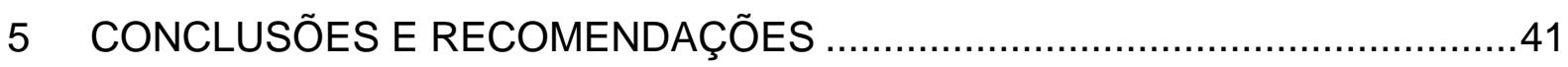

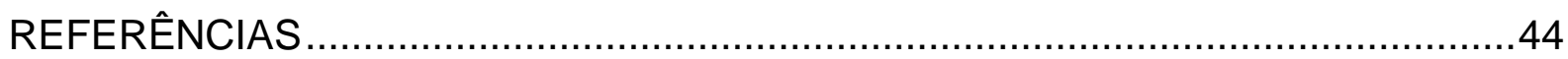

Anexo A - Estudo de Caso na Empresa Tecno Toner............................................46

Anexo B - Histórico e Funcionamento das Impressoras a Laser ...............................52

Anexo C - Remanufatura do Cartucho HP CE505 A/X ...........................................53 


\section{INTRODUÇÃO}

Face à competitividade no meio corporativo e a crescente sensibilidade ecológica da sociedade, as organizações modernas buscam soluções que otimizem recursos e agreguem valor aos seus produtos e serviços perante seus consumidores e clientes. Novos modelos competitivos empresariais mostram que a empresa moderna deve competir, cooperar e inovar ao mesmo tempo.

Assim, para atender as expectativas de consumidores e clientes, reduzir custos operacionais, além de cumprir as exigências legais quanto às normas ambientais, implanta-se nas organizações programas de logística inversa.

\subsection{Contextualização}

Nas últimas décadas nota-se uma grande preocupação com a preservação do meio ambiente, principalmente em virtude das constantes mudanças ambientais, como o aquecimento global e o aumento de catástrofes na natureza.

Percebe-se que os consumidores estão cada vez mais interessados nas questões ambientais. Além disso, constata-se um maior rigor na aplicação da legislação ambiental, acarretando pesadas multas às empresas que ferem, de alguma forma, essas leis.

Questões como a preocupação com a sustentabilidade e a inserção de ações ambientais no seu processo decisório e no seu planejamento, colocam a empresa no mercado com um diferencial competitivo, agregando valor ao seu produto. Surgese assim nas organizações o processo de logística reversa, que é uma das ferramentas que reflete a responsabilidade ambiental agregada à recuperação de valor dos produtos (GUARNIERI et al., 2006; LEITE, 2003).

O descarte de produtos é cada vez maior, principalmente pelas inovações tecnológicas constantes que tornam os produtos obsoletos de forma muito rápida, reduzindo, assim, o tempo de vida útil desses bens. O desequilíbrio existente entre as quantidades descartadas e reaproveitadas torna o gerenciamento dos resíduos 
sólidos urbanos um dos mais graves problemas ambientais da atualidade (GUARNIERI e LEITE, 2003).

Por meio da logística reversa, as empresas serão responsáveis pela devida destinação final de seus produtos, deixando de ocorrer o descarte inadequado por parte do mercado consumidor. Vale ressaltar o grande benefício que é dar um tratamento adequado aos resíduos industriais. Pois, lançados nos aterros sanitários há a contaminação do meio ambiente, da flora e da fauna, e conseqüentemente, dos seres humanos.

Diante do exposto, crescem nas instituições públicas e privadas ações como, por exemplo, a reciclagem e reutilização dos cartuchos de toner ou tinta. Tais medidas reduzem os impactos ambientais, como a poluição do ar, do solo e da água; evita o desperdício e minimiza o esgotamento dos recursos não-renováveis.

Nesse contexto, a Logística Reversa apresenta-se como uma ferramenta empresarial para a diminuição dos impactos ambientais e a recuperação de valor dos produtos.

\subsection{Formulação do problema}

Crescimento populacional, industrialização e grande avanço tecnológico, todos esses fatos têm contribuído para o descarte cada vez maior de resíduos sólidos, prejudicando o meio ambiente. Por outro lado, a organização que tem como objetivo comandar o mercado, ou até mesmo continuar nele, não poderá se descuidar das questões relacionadas à logística reversa, haja vista um maior interesse e uma crescente conscientização ambiental por parte dos consumidores.

Os custos de produtos reciclados geralmente são maiores que os custos de materiais fabricados com matérias-primas "virgens". Nesse sentido, a atualidade apresenta um grande desafio aos administradores, como diminuir os impactos ambientais e obter vantagem econômico-financeira com a política de logística reversa no Brasil? 


\subsection{Objetivo Geral}

Descrever um processo de fluxo inverso de devolução de material, para tornar-se referência básica em logística reversa, com o objetivo de diminuir os impactos ambientais e obter vantagem econômico-financeira.

\subsection{Objetivos Específicos}

- Descrever, a partir de um estudo de caso, procedimentos e processos de logística reversa realizados pela empresa Tecno Toner Cartuchos para Impressoras.

- Apontar os benefícios gerados ao meio ambiente, como a economia de energia, a diminuição da poluição e do desperdício, por meio da reutilização das carcaças de toner e dos cartuchos de tinta das impressoras.

- Identificar que é possível obter ganhos econômicos e tornar eficiente a utilização de canais de retorno de materiais pós-consumo.

\subsection{Justificativa}

O momento atual mostra uma sociedade preocupada com as questões ambientais, onde as pessoas a cada dia compreendem a importância sobre o que é produzido, como é produzido e qual será a destinação dos produtos após o consumo. Em virtude dessa inquietação com as causas do meio ambiente, percebe-se uma alteração nos hábitos de consumo.

Porém, essa mudança de hábito dos consumidores está sendo gradativa e não será suficiente. Razzolini Filho \& Berté argumentam: “(...) No entanto, não devemos nos enganar - sem uma participação efetiva das organizações empresariais e públicas, não será possível modificarmos o quadro atual e, consequentemente, os efeitos serão danosos para toda a vida no planeta" (RAZZOLINI FILHO e BERTÉ, 2009, p. 118). 
Vale destacar que são as empresas e as indústrias os maiores responsáveis pelos danos causados ao meio ambiente por todos os produtos e matérias-primas que fabricam.

Em qualquer processo de produção é utilizada uma determinada energia. $\mathrm{O}$ uso dessa energia causa algum tipo de ação ao meio ambiente. Dessa forma, o consumo de energia no processo produtivo deve ser realizado de forma mais otimizada e consciente. Outra forma de as organizações economizarem energia é a utilização dos canais reversos.

Desse modo, com a participação efetiva das organizações e dos consumidores no tocante a mudança de hábito de consumo, toda a sociedade será beneficiada com essa combinação de esforços. É importante ressaltar que a mudança de foco dos consumidores para as questões ambientais forçará as empresas a alterarem seus processos logísticos para se adequarem a tais exigências, caso contrário não obterão vantagens competitivas e, por consequência, perderão espaço no mercado, podendo, inclusive, serem obrigadas a fecharem suas portas.

Justifica-se o presente trabalho pela importância do assunto abordado e como forma de contribuir numa área de muita carência literária, principalmente no Brasil onde esses estudos ainda estão em seu início. Busca-se apresentar as razões para 0 estudo da logística reversa e seus benefícios para as questões ambientais, a sociedade, como também para as organizações, seja agregando valor aos seus produtos ou identificando formas eficientes para o uso de canais inversos de insumos. Sendo ainda um instrumento motivador da conscientização ambiental, dando oportunidade aos consumidores de ajudarem na preservação do meio ambiente. 


\section{REFERENCIAL TEÓRICO}

Para descrever um processo de fluxo inverso de material e seus benefícios quanto à redução dos impactos ambientais e a obtenção de ganhos econômicos, faz-se necessário iniciar o referencial teórico deste estudo conceituando logística e sua evolução, passando pela definição de logística reversa, sua evolução, a questão ambiental e os aspectos econômico-financeiros.

Também são apresentados os fluxos logísticos e o fluxo inverso, a vantagem competitiva, o fluxo de operações e logísticas, sistema de administração de recuperação de produtos e, finalmente, o conceito de reciclagem.

\subsection{Logística Direta}

A principal associação mundial de profissionais de gestão de cadeias de abastecimento, Council of Supply Chain Management Professionals (CSCMP), traz a seguinte definição:

"Logística é a parte do Gerenciamento da Cadeia de Abastecimento que
planeja, implementa e controla o fluxo e armazenamento eficiente e
econômico de matérias-primas, materiais semi-acabados e produtos
acabados, bem como as informações a eles relativas, desde o ponto de
origem até o ponto de consumo, com o propósito de atender às exigências
dos clientes" (CARVALHO, 2002, p. 31). O termo "logística" foi dito pela primeira vez pelo Barão de Jomini no ano de 1838. Entretanto, a logística já era utilizada na antiga Grécia, Roma e no Império Bizantino, quando os militares com a denominação de Logistikas tinham a função de transportar as tropas, armamentos, equipamentos, recursos e suprimentos às regiões dos combates. As guerras duravam muito tempo, sendo necessário, portanto, planejar, organizar e realizar as atividades logísticas.

No campo acadêmico, segundo Tixier, Mathe e Colin (1986) apud Razzolini Filho e Berté (2009), as primeiras formações universitárias ocorreram na década de 50, nos Estados Unidos, e nos anos de 1970, na França. A partir dos anos 80, há uma grande evolução na logística, principalmente com a globalização, mudanças na 
economia mundial e inovações tecnológicas, como o uso dos computadores na administração. Fleury (2000) apud Filho e Berté, 2009, p. 22, descreve:

\begin{abstract}
"A logística no Brasil está passando por um período de extraordinárias mudanças. Pode-se mesmo afirmar que estamos no limiar de uma revolução, tanto em termos das práticas empresariais quanto da eficiência, qualidade e disponibilidade da infraestrutura de transportes e comunicações, elementos fundamentais para a existência de uma logística moderna".
\end{abstract}

A logística apresenta-se como uma ferramenta fundamental para as organizações nos dias de hoje, haja vista que são as empresas mais flexíveis e ágeis que conquistam o mercado. Nesse sentido, pode-se afirmar que condições favoráveis e competitivas às organizações são possibilitadas pela administração de bons sistemas de logística.

\title{
2.1.1 Evolução
}

Na tabela a seguir, o desenvolvimento dos sistemas logísticos:

\begin{tabular}{|c|c|c|c|}
\hline Período & $\begin{array}{l}\text { O que acontece no } \\
\text { ambiente das } \\
\text { organizações }\end{array}$ & $\begin{array}{c}\text { Visão } \\
\text { organizacional } \\
\text { (ênfase) }\end{array}$ & Foco da logística \\
\hline $\begin{array}{l}1950- \\
1960\end{array}$ & $\begin{array}{c}\text { Busca por escala de } \\
\text { produção (volume). Surge o } \\
\text { conceito de Lote Econômico } \\
\text { de Fabricação e de } \\
\text { Compras (LEF e LEC). }\end{array}$ & $\begin{array}{l}\text { Redução de custos } \\
\text { constante. }\end{array}$ & $\begin{array}{l}\text { Gerenciamento dos } \\
\text { inventários } \\
\text { (preocupação com } \\
\text { estoques). }\end{array}$ \\
\hline $\begin{array}{l}1960- \\
1970\end{array}$ & $\begin{array}{c}\text { Necessidade de incremento } \\
\text { nas vendas. Surgem os } \\
\text { primeiros supermercados } \\
\text { (mudanças radicais no } \\
\text { varejo). }\end{array}$ & $\begin{array}{l}\text { Busca de } \\
\text { diferenciação pelo } \\
\text { serviço ao cliente. }\end{array}$ & $\begin{array}{l}\text { Distribuição física } \\
\text { (visando criar } \\
\text { utilidade espacial). }\end{array}$ \\
\hline $\begin{array}{l}1970- \\
1980\end{array}$ & $\begin{array}{c}\text { Primeira "Crise do Petróleo" } \\
\text { (1973). Movimento de } \\
\text { investimento de capitais. }\end{array}$ & $\begin{array}{l}\text { Necessidade de } \\
\text { obter lucros para } \\
\text { remunerar os } \\
\text { capitais. }\end{array}$ & $\begin{array}{l}\text { Processos } \\
\text { produtivos, visando } \\
\text { reduzir os tempos de } \\
\text { ciclo e minimizando } \\
\text { estoques em } \\
\text { processos. }\end{array}$ \\
\hline $\begin{array}{l}1980- \\
1990\end{array}$ & $\begin{array}{c}\text { Competição acirrada } \\
\text { provocada pelo crescimento } \\
\text { de participação das } \\
\text { empresas japonesas no } \\
\text { mercado mundial. }\end{array}$ & $\begin{array}{c}\text { Busca por } \\
\text { melhorias nos } \\
\text { processos } \\
\text { produtivos visando } \\
\text { certificação na } \\
\text { qualidade. }\end{array}$ & $\begin{array}{l}\text { Integração dos } \\
\text { processos de } \\
\text { compras, produção e } \\
\text { distribuição. }\end{array}$ \\
\hline
\end{tabular}




\begin{tabular}{|c|c|c|c|}
\hline $\begin{array}{l}1990- \\
2000\end{array}$ & $\begin{array}{c}\text { Incremento da globalização } \\
\text { dos mercados. } \\
\text { Terceirização (out- } \\
\text { sourcing). Questões } \\
\text { ambientais. }\end{array}$ & $\begin{array}{l}\text { Competição } \\
\text { baseada em } \\
\text { rapidez de } \\
\text { resposta. }\end{array}$ & $\begin{array}{l}\text { Processos de } \\
\text { gerenciamento } \\
\text { (visando criar } \\
\text { utilidade temporal). }\end{array}$ \\
\hline 2000- & $\begin{array}{c}\text { Crises no processo de } \\
\text { globalização. Formulação } \\
\text { de alianças nas cadeias } \\
\text { produtivas. Ampliação dos } \\
\text { conceitos de } \\
\text { responsabilidade social e } \\
\text { ecológica. }\end{array}$ & $\begin{array}{l}\text { Preocupação com } \\
\text { presença local } \\
\text { (instalação física } \\
\text { próxima aos } \\
\text { principais } \\
\text { mercados) e } \\
\text { rapidez de } \\
\text { respostas. }\end{array}$ & $\begin{array}{l}\text { Processos flexíveis e } \\
\text { ágeis. Implantação } \\
\text { de sistemas } \\
\text { logísticos de } \\
\text { resposta rápida. }\end{array}$ \\
\hline
\end{tabular}

Quadro 1: Sinopse da evolução dos sistemas logísticos

Fonte: Razzolini Filho e Berté, 2009, p. 32 e 33.

Percebe-se que ocorrem constantes alterações nos processos organizacionais dos sistemas logísticos. Essas mudanças são evoluções em virtude do surgimento de novas teorias, como também de fatores sociais, culturais, políticos e econômicos. Dessa forma, a logística deve se adaptar às variações advindas tanto do meio interno quanto do meio externo.

Vale destacar que essa evolução não representa que a visão organizacional ou o foco da logística foi suprimido nos períodos subseqüentes. Na realidade, os conhecimentos obtidos em cada período foram reunidos e aprimorados durante as fases, demandando muito mais capacidade dos profissionais envolvidos.

A atualidade nos apresenta uma logística preocupada também com as questões ambientais e sociais. Assim, as organizações devem atuar não só no atendimento e satisfação das necessidades dos seus clientes, como também devem antecipar-se às necessidades sócio-ambientais.

As empresas buscam a sustentabilidade de seus produtos e/ou serviços. Conforme o Relatório Brundtland (1987), documento elaborado pela Comissão Mundial sobre Meio Ambiente e Desenvolvimento, sustentabilidade é "suprir as necessidades da geração presente sem afetar a habilidade das gerações futuras de suprir as suas”.

Segundo os autores Razzolini Filho e Berté (2009), com as exigências cada vez maiores da sociedade quanto à responsabilidade socioambiental, obterão vantagem competitiva sobre a concorrência as empresas que, por meio da integração e interligação das áreas responsáveis pelo suprimento e distribuição de materiais, combinarem suas preocupações com os custos operacionais e a questão ambiental. 
Nota-se que essas organizações planejam o ciclo de vida de seus produtos de forma que possam, após a utilização, reciclá-los, proceder à revenda de parte dos materiais, ou ainda, dar-lhes uma destinação final apropriada. Dessa forma, o sistema de logística tradicional ou direta amplia-se com o desenvolvimento do fluxo reverso de produtos, serviços e informações.

\title{
2.2 Logística Reversa
}

A criação e as exigências cada vez maiores de legislações e normas por parte das autoridades governamentais e a maior conscientização da sociedade em relação às causas ambientais, face às mudanças climáticas e outras questões ambientais, criaram a necessidade e a oportunidade de as organizações agregarem valor aos seus produtos e obterem vantagem competitiva por meio de seus sistemas logísticos, especificamente a área de logística reversa.

Segundo os autores Rogers e Tibben-Lembke, logística reversa é:

\begin{abstract}
"O processo de planejamento, implementação e controle da eficiência e custo efetivo do fluxo de matéria-prima, estoques em processo, produtos acabados e as informações correspondentes do ponto de consumo para o ponto de origem com o propósito de recapturar valor ou realizar o descarte adequado" (ROGERS e TIBBEN-LEMBKE, 1998, apud ANDRADE, E.M.; FERREIRA, A.C.; SANTOS, F.C.A. Tipologia de Sistemas de Logística Reversa Baseada nos Processos de Recuperação de Valor: estudo de três casos empresariais. In: Anais do SIMPOI, São Paulo, Brasil, 2009).
\end{abstract}

Citando Dias, 2005, p. 205, “logística reversa, também conhecida como logística inversa, reversível ou verde, é a área da logística que trata, genericamente, do fluxo físico de produtos, embalagens ou outros materiais, desde o ponto de consumo até ao local de origem".

A definição pela Council of Supply Chain Management Professionals (CSCMP) de logística reversa:

"É a parte do processo da cadeia de abastecimento que planeja, implementa e controla o eficiente e eficaz fluxo direto e inverso (logística inversa), e a armazenagem de produtos, serviços e informação relacionada, desde o ponto de origem até ao ponto de consumo, com o propósito de satisfazer os requisitos dos clientes". 
Já os autores Razzolini Filho e Berté, 2009, p. 63, afirmam que a logística reversa, além da reutilização de recipientes e reciclagem de materiais de embalagens, também pode compreender as seguintes atividades:

$>$ O processamento dos materiais retornados em função de danos, estoques sazonais, destinação de equipamentos obsoletos (leilões, sucateamento, etc.);

As atividades de remanufatura e recondicionamento;

Os programas de reciclagem, tratamento de produtos perigosos e a recuperação do recurso.

Percebe-se que os propósitos da logística inversa é o planejamento, execução e controle de maneira eficiente e eficaz, quanto ao fluxo inverso de produtos; diminuição do consumo de matérias-primas; reciclagem, troca e reutilização de materiais; reprocessamento e remanufatura de peças e produtos; destinação final de materiais e resíduos de forma adequada.

\subsubsection{Evolução}

As atividades de logística reversa, apesar de não ser tratada como tal, existem há algum tempo. Como por exemplo, o retorno das garrafas de refrigerantes e de cerveja, a coleta do lixo e de materiais recicláveis.

Há pouco mais de duas décadas é que se iniciou com mais ênfase os estudos sobre a sistematização dos processos logísticos inversos. Tais estudos foram estimulados, grande parte, pelas preocupações provocadas na sociedade no tocante às questões ambientais, em virtude do grande crescimento econômico, da indústria e da população.

Essas preocupações derivam, principalmente, em relação à destinação das embalagens dos produtos, do retorno de produtos defeituosos e de sua restauração, do retorno dos produtos pós-consumo, bem como do tratamento ou deposição final dos resíduos industriais. 
Outro aspecto relevante que impõe a necessidade de implementar um sistema logístico inverso nas empresas são as vendas pela Internet, o chamado e-commerce (Carvalho, 2003). Com o aumento extraordinário das vendas, nesse tipo de comércio, e em razão da impossibilidade de visualização ou percepção física e precisa do produto, ou da sua qualidade, na compra efetuada por meio eletrônico, ocorrem muitas devoluções de mercadorias por não atenderem as expectativas desses consumidores. Dessa forma, as empresas precisam promover soluções ou sistemas logísticos inversos para melhor administrar essa situação.

\subsubsection{A Questão Ambiental e os Aspectos Econômico-financeiros}

Atualmente, a reciclagem ainda é incipiente. Pode-se excluir dessa regra, a reciclagem das latas de alumínio e a sucata de aço de automóveis. Isso decorre porque, normalmente, os custos logísticos com matérias-primas não recicladas são menores do que com materiais reciclados.

No entanto, percebe-se uma gradual mudança de atitude na sociedade, organizações públicas e privadas. Um exemplo dessa mudança de hábitos é a separação dos resíduos sólidos do lixo orgânico. Segundo Cardoso, 2006, apud Razzolini Filho e Berté, 2009, p. 57, na evolução da perspectiva sobre como tratar do lixo que a humanidade acumula, "a cada dia que passa, a logística reversa, ainda pouco explorada no país, ganha força e espaço no mercado, seja pelo importante apelo ambiental ou pela redução potencial de custos". Ainda, conforme Cardoso, o sistema logístico reverso terá mais importância devido a dois fatores: o foco ambiental e o foco econômico-ambiental.

O foco ambiental trata de atividades de logística reversa relativas às questões ambientais em virtude de uma maior conscientização por parte dos administradores no tocante a fatores de preservação e conservação do meio ambiente.

Nesse enfoque, apresentam-se atuações como:

- O desenvolvimento de métodos que possibilitem o retorno de embalagens para o processo produtivo, como por exemplo, a implementação de embalagens retornáveis; 
- A procura dos produtos e/ou resíduos pós-consumo, como as baterias de aparelhos celulares.

O propósito dessas ações de fluxos inversos é a busca pela melhoria de imagem da organização e uma forma de agregar valor aos seus produtos, haja vista o aumento constante de um maior entendimento por parte de consumidores e usuários no diz respeito aos danos ambientais que os produtos das organizações podem acarretar.

Além desse maior entendimento das questões ambientais por parte dos consumidores, as empresas buscam adequar-se às legislações e exigências das autoridades governamentais, seja de países desenvolvidos ou em desenvolvimento, como por exemplo, os selos verdes ou certificação ambiental, além das normatizações da Série ISO 14000.

O foco econômico-financeiro é retratado pelo autor Cardoso da seguinte forma:

"(...) visa recuperar custos de produção por meio do retorno de produtos
pós-consumo para a cadeia de abastecimento, em virtude de escassez e ou
encarecimento de matérias-primas. Entre os segmentos industriais que já
praticam a logística reversa para resíduos, subprodutos e embalagens,
destacam-se as indústrias de componentes eletrônicos, as montadoras
automobilísticas e a indústria de cosméticos. Em alguns países, isso já é
prática bastante difundida e os resultados obtidos com a logística reversa
são expressivos". (Cardoso, 2006, apud Razzolini Filho e Berté, 2009, p.
59 ).

Ainda segundo Cardoso (2006), os gestores buscarão soluções nos sistemas logísticos inversos, o que promoverá ainda mais essa área. Outra colocação do autor é em relação à relevância das atividades de logística reversa na cadeia de suprimentos para agregar valor aos seus produtos e marca, e, primordialmente, na diminuição dos custos diretos.

Há uma tendência muito forte, conforme Lacerda, 2002, apud Razzolini Filho e Berté, 2009, de que a legislação ambiental se tornará mais exigente e vigorosa no tocante à responsabilidade integral das organizações quanto ao ciclo de vida dos seus produtos e a todos os fatores da destinação dos produtos após a entrega aos clientes e aos danos que esses produtos podem acarretar ao meio ambiente.

Razzolini Filho e Zarpelon, 2003, apud Razzolini Filho e Berté, 2009, p. 62, comentam o fato de a logística reversa considerar os "aspectos de gestão ambiental, adequada com padrões de ecodesenvolvimento, além de gerar impulso para novas tecnologias e bioprocessos de reaproveitamento e reciclagem". Portanto, esse 
sistema logístico, por si só, é fundamental para a melhoria da imagem das empresas que a utilizam.

De acordo com Leite (2003), nos sistemas logísticos reversos pode ocorrer o direcionamento dos bens, pós-consumo, para um novo ciclo de transação comercial. Ou seja, os produtos já consumidos são transformados em novas matérias-primas de um novo processo produtivo.

Bronoski (2003) afirma que "a logística reversa se aplica tanto como um fator de redução de custos na cadeia produtiva como um meio de preservação ambiental". Sendo assim, pode-se concluir que a otimização no uso dos produtos e matériasprimas, e a reutilização, proporcionam melhores resultados econômicos para as organizações e causam menos impactos ao meio ambiente.

\subsubsection{Fluxos Logísticos e Fluxo Inverso}

Segundo os autores Bowersox e Closs, 2001, apud Razzolini Filho e Berté, 2009, p. 66, quanto à implantação da logística na administração de uma empresa, afirmam que "desde seu surgimento, a logística concentrou-se no fluxo eficiente de bens ao longo do canal de distribuição". Pois, a comercialização de produtos por uma empresa, exige um sistema logístico que realize a movimentação dos materiais, desde a compra ou produção, armazenagem e distribuição, iniciada através de solicitações ou pedidos, mediante canais de comunicação. Tudo isso, se não for muito bem administrado, pode acarretar em custos adicionais para a organização.

$\mathrm{Na}$ área da logística, há um consenso entre os autores, no tocante aos fluxos logísticos. Os quais são divididos em:

- Fluxo físico - movimentação dos materiais;

- Fluxo financeiro - pagamento dos materiais;

- Fluxo de informações - realiza a interação entre o fluxo físico e o fluxo financeiro.

Outro ponto convergente é a maior importância dada pelos autores ao fluxo de informações, por ser o responsável pelo funcionamento dos fluxos físico e financeiro. 
Razzolini Filho e Berté, 2009, p. 67, citam “(...) a importância de informações de qualidade (notórias, oportunas, consistentes e úteis) para dar suporte ao processo decisório organizacional”.

Os autores também mencionam que, para alcançar agilidade e flexibilidade no fluxo informacional, exigências do atual contexto ambiental no qual a logística faz parte, é essencial o uso da tecnologia da informação. Dessa forma, busca-se a transmissão e gerenciamento das informações por meio de suporte eletrônico, "com maior eficiência, eficácia e rapidez" (Bowersox; Closs, 2001, apud Razzolini Filho e Berté, 2009, p. 67), para obter-se diminuição dos custos logísticos.

Razzolini Filho e Berté, 2009, p. 68, no que diz respeito aos fluxos logísticos, citam que os produtos podem percorrer três caminhos diferentes:

Da fábrica até o armazém ou centro de distribuição;

Do centro de distribuição até o autosserviço ou varejo;

Do autosserviço, ou varejo, até o consumidor.

Pelos motivos já mencionados anteriormente, como preocupações ambientais, retorno de produtos defeituosos e pós-consumo, destinação final dos produtos e dos resíduos industriais, etc, pode-se ponderar para um quarto fluxo logístico, o da logística reversa, ou seja, o fluxo inverso consumidor-varejo-indústria.

A seguir uma demonstração do quarto fluxo logístico, o fluxo inverso:
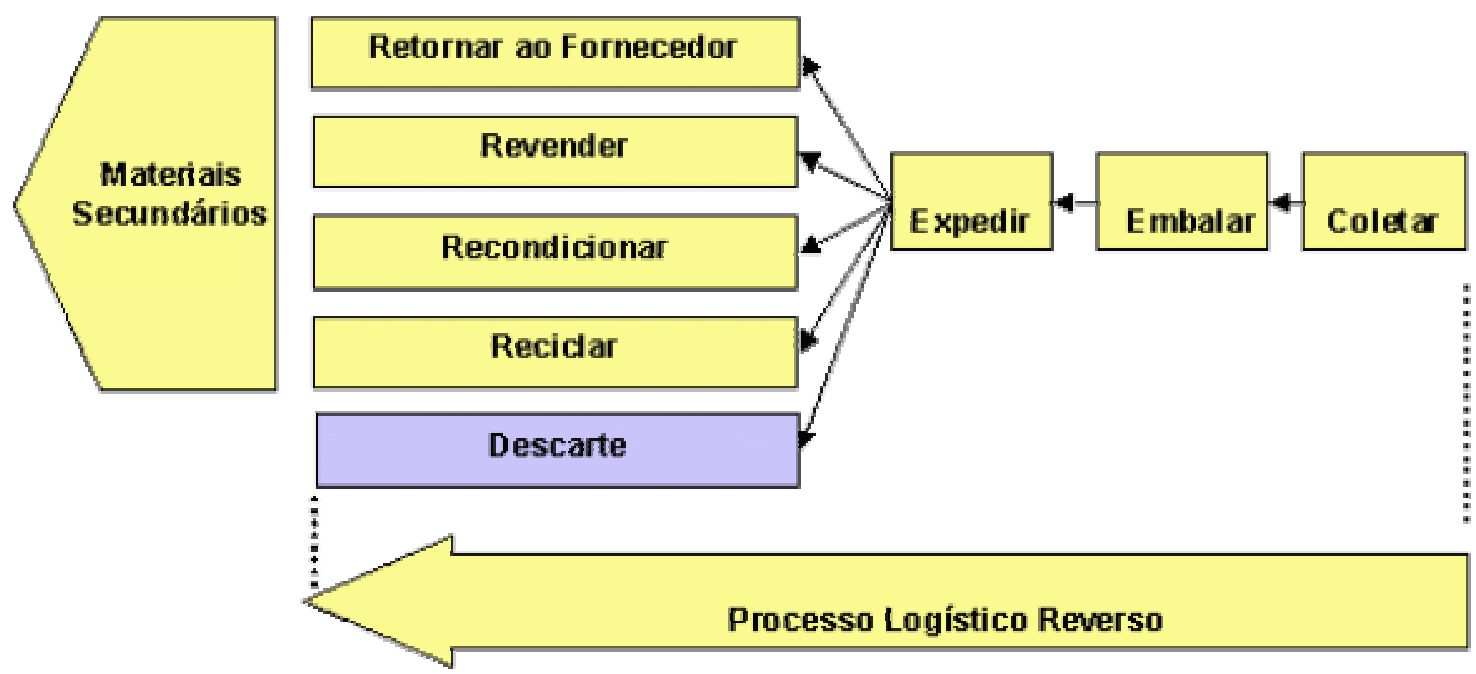

Figura 1: Atividades mais comuns do processo logístico inverso Fonte: Going Backwards

Autor: Vasco Neves Dias 
De acordo com Razzolini Filho e Berté (2009), face a quantidade de pontos de coleta a serem alcançados nesse processo, o quarto caminho certamente é o mais complexo. Contudo, para as organizações que realizarem essa integração com eficiência e eficácia conquistarão ganhos frente à concorrência.

Os autores também comentam que para introduzir o sistema logístico reverso com o propósito de alcançar ganhos econômicos pelo melhor aproveitamento dos recursos disponíveis, torna-se necessário elaborar sistemas logísticos com uma visão abrangente, procurando interligar os processos necessários para a realização das atividades logísticas.

Percebe-se claramente o desenvolvimento da logística e a ampliação de suas atividades que abrangem a movimentação de produtos e informações. Segundo Dornier et al., 2000, apud Razzolini Filho e Berté, 2009, p. 71:

“(...) fluxos diretos e reversos ocorrem entre as estruturas internas da organização (gerenciadas tanto pela própria organização quanto por uma empresa fornecedora de serviços logísticos), ou entre a estrutura interna e uma externa - por exemplo, um cliente e um fornecedor".

Assim, conforme esses autores os fluxos inversos abrangem os fatores a seguir:

- Fornecedores - manuseamento de embalagens e reparo;

- Fabricantes - processamento da reciclagem ou reprocessamento e tratamento dos resíduos industriais;

- Clientes - nos processos de redução de estoques ou de consertos.

No contexto atual de preocupações com as questões ambientais por parte dos consumidores tem-se conduzido à criação de leis e normas cada vez mais exigentes no que diz respeito à responsabilidade ampliada dos produtos. Assim, de acordo com Razzolini Filho e Berté (2009), o fabricante torna-se responsável, não só no instante da venda, do consumo ou do uso do produto, essa responsabilidade é ampliada para o momento em que o produto é reintegrado ao ciclo produtivo ou é efetuada à sua destinação final. 


\subsubsection{Vantagem Competitiva}

Diante desse cenário de sensibilidade ecológica, as organizações, mesmo aquelas com propósito exclusivamente econômico, vêm tentando valer-se das questões socioambientais para obter vantagem competitiva.

Stock, 2001b, apud Razzolini Filho e Berté, 2009, p. 73, menciona vários "pecados" praticados em logística reversa, dentre os quais destaca-se:

Pecado no 1: "Não reconhecer que a logística reversa representa fator que cria vantagens competitivas".

Pecado no 4: "Supor que esforços parciais são suficientes para o tratamento das questões de logística reversa".

A explicação para esses "pecados" são os dois aspectos em que se podem classificar os ganhos obtidos pelas organizações a partir da logística reversa, ou seja:

- Na concorrência, pela prestação diferenciada de serviço. O estabelecimento de um sistema logístico reverso melhora a imagem da empresa perante os consumidores, não obstante o fato de ser ou não uma exigência da legislação;

- Nos custos, pela otimização dos recursos em virtude da reutilização ou reaproveitamento de matérias-primas, bem como o uso de embalagens retornáveis.

Bertaglia, 2003, apud Razzolini Filho e Berté, 2009, p. 74, considera dois tipos de fluxos nos sistemas logísticos:

$>$ O fluxo tradicional (a jusante), do fabricante em direção ao consumidor;

$>$ O fluxo ao qual não se dá tanta atenção e que tem o sentido contrário - a logística reversa -, que vai do consumidor para o fabricante (montante).

Razzolini Filho e Berté (2009) afirmam que de um modo geral as organizações são capazes e eficientes na distribuição tradicional (a jusante). No entanto, em relação à logística reversa, não são competentes da mesma forma. Segundo Razzolini Filho e Zarpelon, 2003, apud Razzolini Filho e Berté, 2009, p. 74, é importante destacar que 
"a logística reversa inclui a distribuição reversa, que faz com os fluxos físicos, de informações e financeiros, sigam na direção oposta das atividades logísticas usuais".

Deve-se ressaltar também que é essencial o uso da tecnologia da informação para ajustar a organização aos fluxos inversos, que são de maior complexidade e abrangência. Porém, devido à diversidade e peculiaridades que são exigidas na elaboração desses softwares, um bom sistema de informações logísticas de fluxo inverso custa um preço alto. Fato esse que torna mais difícil a implantação de sistemas logísticos reversos.

De acordo com Leite, 2003, apud Razzolini Filho e Berté, 2009, p. 75:

"Os produtos de retorno são considerados ainda, em grande parte, um
'problema' a ser resolvido e geralmente os sistemas de informações da
distribuição direta não incluem os retornos de pós-venda, o que dificulta o
controle dos fluxos de toda a cadeia reversa".

Razzolini Filho e Berté, 2009, p. 75, também destacam que "é a necessidade da criação de programas educacionais para fornecedores, colaboradores, vendedores, consumidores e demais elos da cadeia de suprimentos". Desse modo, busca-se aumentar a conscientização socioambiental, motivando também a agregação de valor em todas as áreas da cadeia de suprimentos.

Outro fator fundamental para a obtenção de um bom sistema de logística reversa é possuir um programa de mensuração do desempenho desses sistemas. "(...) mensuração é a competência que busca medir custos, recursos, tempo e qualidade da ação logística, procurando medir eficiência, tendência e competitividade" (CLM, 1995, apud Razzolini Filho e Berté, 2009, p. 75).

Esses sistemas de mensuração, segundo Razzolini Filho e Berté, 2009, p. 75, devem abranger três características principais:

- Avaliação funcional - é a avaliação periódica de todas as atribuições relativas ao fluxo reverso para definir sua eficiência e eficácia no que diz respeito aos objetivos pretendidos;

- Avaliação processual - é o acompanhamento permanente dos processos de mensuração, podendo ser revistos esses processos se os resultados apresentados não forem os pretendidos;

- Benchmarking (interno, competitivo e não restritivo) - é o acompanhamento permanente dos ambientes interno e externo da organização. O objetivo é a 
procura de procedimentos que possam ser introduzidos na organização para conferir-Ihe uma maior competitividade.

Conforme mencionam Razzolini Filho e Berté (2009), os ganhos advindos dos sistemas logísticos reversos e que geram vantagens competitivas às organizações podem ser classificados sob dois aspectos:

- Melhoria da imagem institucional perante seus consumidores, principalmente naqueles mercados onde há uma maior conscientização ecológica e social, desde que sejam divulgadas como atuações de marketing socioambiental e estejam abrangidas pelos sistemas logísticos da empresa;

- Diminuição de custos operacionais. Essa redução pode ser obtida sob dois pontos: pela reciclagem, reutilização ou reaproveitamento de matérias-primas e materiais; e pela economia de energia e combustíveis ou qualquer outro tipo de insumo, como embalagens.

Os mesmos autores destacam que, para a empresa alcançar os propósitos de competitividade, as atividades desenvolvidas na logística reversa devem ser planejadas em conjunto com os diversos setores da organização.

Em pesquisa apresentada por Rogers e Tibben-Lembcke (1998), os objetivos estratégicos que definem a realização dos canais reversos pelas organizações, mostrou os seguintes resultados por ordem de respostas:

- Aumentar a competitividade - obter ganhos de imagem junto aos consumidores ou usuários;

- "Limpar" o canal por meio da diminuição de estoques sem movimentação - é o fornecimento ao cliente de estoques mínimos;

- Obedecer às normas e legislação - apesar de tratar-se de uma exigência legal, pode-se gerar vantagem competitiva se o sistema logístico reverso for bem aplicado;

- Revalorização econômica - é o retorno de um material que pode ser aproveitado em outro processo produtivo para obter ganho econômico;

- Recuperar valor de ativos - é o aproveitamento de parte de ativos fixos ou de materiais com o objetivo de recapturar valor. 


\subsection{Fluxo de Operações e Logística}

Razzolini Filho, 2004, apud Razzolini Filho e Berté, 2009, p. 91, define gerenciamento dos canais reversos de distribuição como "as atividades logísticas em que uma organização se ocupa da coleta de seus produtos usados, danificados ou ultrapassados, embalagens e/ou outros resíduos finais gerados pelos seus produtos".

De acordo com Dornier et al., 2000, apud Razzolini Filho e Berté, 2009, p. 91, "as principais famílias de fluxos de operações e logística são caracterizadas pela direção destes e pelas relações de fluxos envolvidos", conforme demonstrado na figura a seguir:

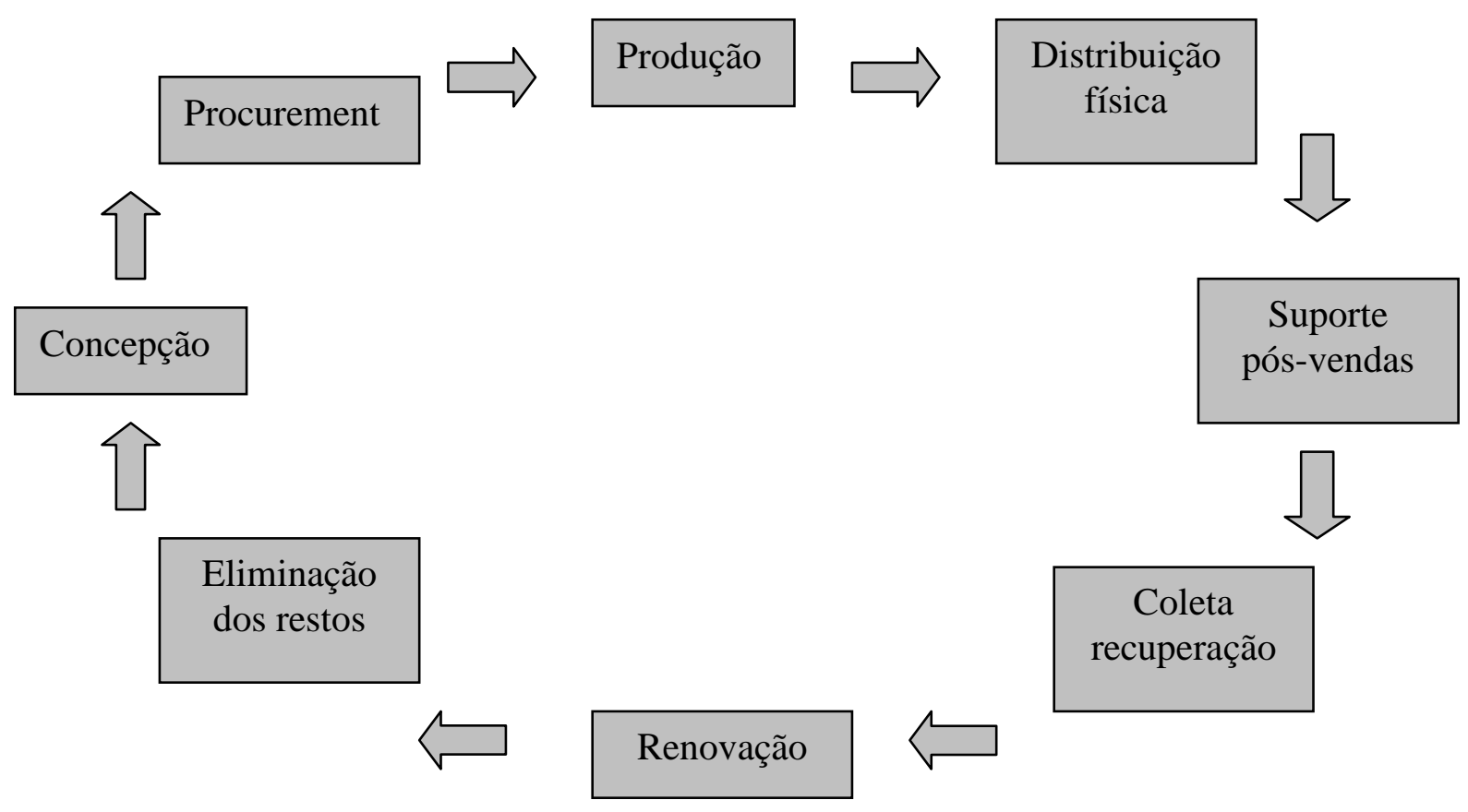

Figura 2: Fluxo de operações e logística

Fonte: Dornier et al., 2000

Conforme apresentado na figura, o ciclo do fluxo de operações e logística abrange as seguintes fases:

- Concepção - é a fase de definição de um novo produto, onde a empresa já se preocupa com as matérias-primas que serão utilizadas;

- Procurement - etapa onde as matérias-primas mais apropriadas são adquiridas; 
- Produção - o ato de fabricar;

- Distribuição física - a expedição ou distribuição ao mercado;

Com o suporte de pós-venda, inicia-se o processo de logística reversa:

- Coleta e a recuperação - o procedimento de coleta e recuperação dos produtos;

- Renovação e Eliminação dos restos - fase onde se procede ao reaproveitamento ou a eliminação dos resíduos caso não possam ser reaproveitados.

\subsection{Administração da Recuperação de Produtos}

Encontra-se em desenvolvimento nos ambientes organizacionais uma área de trabalho denominada Product Recovery Management (PRM) - Administração da Recuperação de Produtos. Segundo Thierry et al., apud Krikke, 1998, apud Razzolini Filho e Berté (2009), é a área responsável da empresa fabricante pela administração dos produtos, seus componentes e todos os materiais, insumos e matérias-primas utilizadas e rejeitadas, seja pela legislação em vigor, contratos ou qualquer outra razão.

Segundo Razzolini Filho e Berté, 2009, p. 97, a PRM demanda diversos aspectos de gerenciamento, dentre eles a logística reversa. PRM refere-se a:

\footnotetext{
“(...) um conjunto de ferramentas de gestão, potencializadas pelas tecnologias web (internet), com o propósito de auxiliar o gerenciamento de canais de venda indiretos pela agregação de serviços e comunicação intensa entre os membros dos canais. Assim, é a PRM que objetiva a recuperação do valor econômico e ecológico dos produtos, bem como de seus componentes e materiais".
}

De acordo com Krikke (1998), apud Razzolini Filho e Berté (2009), existem quatro níveis em que os produtos que regressam à cadeia podem ser restaurados: nível de produto, de módulos, partes componentes e materiais. Para a PRM, essa classificação transforma-se em cinco processos: reparo, renovação, remanufatura, canibalização e reciclagem, os quais resultarão em novos produtos.

Para os autores Daher, Silva e Fonseca (2004), apud Razzolini Filho e Berté (2009), de acordo com as opções de PRM usadas pela organização, podendo ser uma ou 
mais opções, o sistema de logística reversa será projetado em razão dessas opções, visto que o planejamento e a organização do sistema logístico inverso com o objetivo de obter o aproveitamento da melhor forma possível dos recursos disponíveis são essenciais ao bom funcionamento da PRM.

A tabela abaixo resume as opções de PRM:

\begin{tabular}{|c|c|c|c|}
\hline Opções de PRM & $\begin{array}{c}\text { Nível de } \\
\text { desmontagem }\end{array}$ & $\begin{array}{l}\text { Exigências de } \\
\text { qualidade }\end{array}$ & Resultado obtido \\
\hline Reparo & Produto & $\begin{array}{l}\text { Restaurar o } \\
\text { produto para pleno } \\
\text { funcionamento. }\end{array}$ & $\begin{array}{l}\text { Algumas partes } \\
\text { reparadas ou } \\
\text { substituídas. }\end{array}$ \\
\hline Renovação & Módulo & $\begin{array}{c}\text { Inspecionar e } \\
\text { atualizar módulos } \\
\text { críticos. }\end{array}$ & $\begin{array}{l}\text { Alguns módulos } \\
\text { reparados ou } \\
\text { substituídos. }\end{array}$ \\
\hline Remanufatura & Parte & $\begin{array}{c}\text { Inspecionar todos } \\
\text { os módulos/partes } \\
\text { e atualizar. }\end{array}$ & $\begin{array}{l}\text { Módulos/partes } \\
\text { usados e novos em } \\
\text { novo produto. }\end{array}$ \\
\hline Canibalização & $\begin{array}{l}\text { Recuperação } \\
\text { seletiva de partes }\end{array}$ & $\begin{array}{l}\text { Dependência do } \\
\text { uso em outras } \\
\text { opções de PRM. }\end{array}$ & $\begin{array}{l}\text { Algumas partes } \\
\text { reutilizadas, outras } \\
\text { descartadas ou } \\
\text { para reciclagem. }\end{array}$ \\
\hline Reciclagem & Material & $\begin{array}{l}\text { Depende do uso } \\
\text { em remanufatura. }\end{array}$ & $\begin{array}{l}\text { Materiais utilizados } \\
\text { em novos produtos. }\end{array}$ \\
\hline
\end{tabular}

Quadro 2: Resumo de opções de recuperação de produtos

Fonte: Krikke, 1998, apud Razzolini Filho e Berté, 2009, p. 98.

Conforme mencionam Razzolini Filho e Berté (2009), a PRM é um instrumento de gestão fundamental, onde está incluída a logística reversa, e que apresenta diferentes opções para o gerenciamento dos canais reversos pós-venda ou pósconsumo, por oferecer diferentes níveis de desmontagem dos produtos que percorrem o sistema logístico tradicional e que, por uma razão qualquer, são transferidos ao sistema logístico reverso.

Ainda segundo esses autores, essa ferramenta de gestão torna possível a obtenção de resultados expressivos no gerenciamento da cadeia logística, como:

- Ações contributivas de comércio, oferecendo mais opções de vendas;

- Otimização dos canais diretos e reversos;

- Boas ligações profissionais entre os participantes do canal, haja vista a melhoria dos processos de comunicação;

- Maior rentabilidade pela recuperação de valor econômico; 
- Melhoria da imagem pela recuperação de valor ecológico.

\subsection{Reciclagem}

Razzolini Filho e Berté (2009) definem reciclagem como o processo de reaproveitamento de materiais descartados que podem ser transformados em novas matérias-primas para a produção de novos produtos. Outra definição de reciclagem é o regresso da matéria-prima ao ciclo de produção, ou ainda, é o conjunto de atividades que compreendem o processo de retorno da matéria-prima.

Esses autores também salientam que o produto obtido em grande parte dos processos de reciclagem difere totalmente do produto original, como também não deve ser reutilizado, em algumas situações, para constituir o produto original. Podese observar claramente que o papel reciclado é bem diferente daquele que foi produzido pela primeira vez, com gramatura, textura e cor, bem diferentes. As embalagens de produtos alimentícios só podem ser produzidas com matérias-primas virgens.

Vale destacar que a lata de alumínio, ao contrário do vidro, pode voltar ao estado original ao ser derretida. Dessa forma, pode-se obter uma nova lata com as mesmas características de uma lata original.

As etapas que compreendem o processo de reciclagem são: coleta, separação, revalorização e transformação. De acordo com os autores Razzolini Filho e Berté (2009), essas etapas podem ser descritas da seguinte forma:

- Coleta - é o recolhimento dos produtos e materiais que são descartados ou depositados pelos consumidores ou usuários;

- Separação - é a triagem dos materiais conforme sua classificação (plástico, vidro, metal, madeira, papel, etc);

- Revalorização - nessa fase, após a separação dos materiais, ocorre a atividade de preparação para a etapa seguinte, que é a transformação em novos produtos; 
- Transformação - é a produção de novos produtos ou insumos a partir do processamento dos materiais revalorizados.

Para o processo de reciclagem e com o propósito de facilitar a coleta dos materiais, foram padronizados símbolos de acordo com a classificação dos diversos tipos desses componentes.

A simbologia de cada tipo de material segue os seguintes padrões:

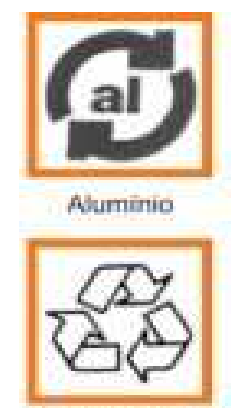

Papel Reciciarvel

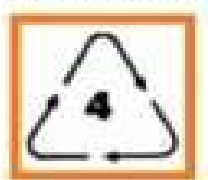

PEBD

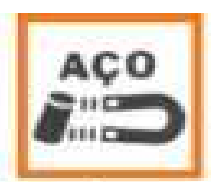

Aço

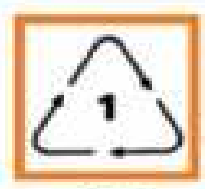

PET

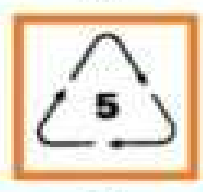

PP

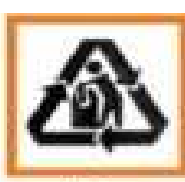

Vidira

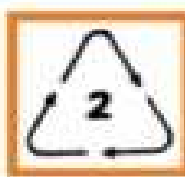

PEAD

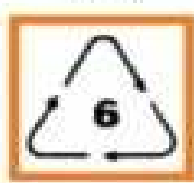

PS

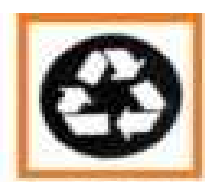

Papal Reciciado

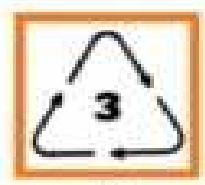

V

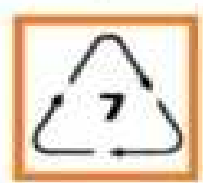

Outros

Figura 3: Símbolos dos recicláveis

Fonte: http://recicleblog.blogspot.com/2008/08/o-que-significam-os-smbolos-dos.html Acesso em: 19 mai. 2010 


\section{MÉTOdOS E TÉCNICAS DE PESQUISA}

“Entende-se a pesquisa como a principal atividade acadêmica, pois é através do conhecimento adquirido através dessa experiência que se pode formular um pensamento crítico e renovador a respeito do tema em estudo". Sílvia Mota (2005).

\subsection{Caracterização da Organização Objeto de Estudo}

Tecno Toner Cartuchos para Impressoras, empresa brasileira fundada em 1990, com matriz localizada em Salto (SP) e filiais de vendas nas cidades de Campinas, Sorocaba, Indaiatuba e Itu, todas no Estado de São Paulo. A empresa também opera nas cidades de Buenos Aires (Argentina) e Miami (Estados Unidos).

A Tecno Toner atua na área de recondicionamento de cartuchos para impressoras a laser e a jato de tinta, com certificações de qualidade e respeito ao meio ambiente, ISO 9001:2000 e ISO 14001:2004. Também presta serviços de assistência técnica em manutenção de impressoras, locação de impressoras e consultoria em impressão, oferecendo seus serviços por todo o Brasil.

Sua Visão: "Ser uma referência em soluções para impressões no mercado nacional e conquistar o mercado internacional".

Sua Missão: Fornecer produtos e serviços que atendam as necessidades dos nossos clientes tendo como diretrizes:

- Desenvolvimento constante de processos de remanufatura e produção de cartuchos para impressoras.

- Promover a capacitação profissional e o trabalho em equipe de seus colaboradores.

- Gerar produtos e serviços competitivos, garantindo retorno financeiro do capital aplicado.

- Investimento constante em tecnologia para melhorar o processo produtivo e a competência do produto final. 
- Ser uma empresa ecologicamente correta, atuando em harmonia com a sociedade, preservando o meio e o ser humano.

Seus Valores: Domínio no trabalho. Inovação e criatividade. Vontade. Responsabilidade. Companheirismo. Consciência ecológica. Humildade.

\subsection{Caracterização do Tipo e Instrumento de Pesquisa}

O tipo de pesquisa adotado para o presente trabalho é descritiva de caráter bibliográfico e documental, com consultas em fontes secundárias, pois se baseou na coleta de informações constantes em livros, artigos publicados na internet, revistas eletrônicas, manuais e documentos fornecidos por instituições privadas, com a finalidade de alcançar seus objetivos.

O método utilizado na pesquisa é de abordagem qualitativa, buscando descrever processos, situações e procedimentos, conforme as manifestações do ambiente.

De acordo com Zanella (2006, pág. 59-89), "a abordagem qualitativa trabalha com dados qualitativos, com informações expressas nas palavras orais e escritas, em pinturas, em objetos, fotografias, desenhos, filmes, etc". Ainda segundo o autor, "o método qualitativo tem sua origem na antropologia e utiliza métodos indutivos, objetivando a descoberta, a identificação, a descrição detalhada e aprofundada".

\subsection{Coleta e Análise dos Dados}

Para a coleta de dados, o instrumento ou técnica de pesquisa utilizado no trabalho em questão é a análise documental e a revisão bibliográfica.

As informações obtidas produziram leituras exploratória, analítica e interpretativa, com o intuito de conceber textos fundamentados, resultados da análise críticoreflexiva do pesquisador, com base nos dados coletados. 


\section{RESULTADOS E DISCUSSÃO}

A logística reversa apresenta-se como uma ferramenta administrativa fundamental às empresas que desejam obter ganhos econômicos e criar uma vantagem competitiva, independente de ser ou não uma exigência legal, frente a consumidores e a sociedade como um todo que se torna cada vez mais exigente com os produtos que escolhem e adquirem, principalmente no que diz respeito à destinação final dos produtos (pós-consumo).

Nesse sentido, a sociedade está mudando seus hábitos de consumo, face ao crescente ambiente de sensibilidade ecológica e maior interesse em questões de preservação do meio ambiente.

Buscou-se com o presente estudo descrever um processo de fluxo inverso de material realizado pela empresa Tecno Toner Cartuchos para Impressoras, apontando os benefícios gerados ao meio ambiente por meio da reutilização das carcaças de toner e identificando os ganhos econômicos advindos desse processo de logística reversa.

A Tecno Toner possui as licenças ambientais obrigatórias para a realização de suas atividades de remanufatura das carcaças usadas de cartucho de toner e as certificações de respeito ao meio ambiente e de qualidade (ISO 14001:2004 e ISO $9001: 2000)$.

A empresa, dada a relevância das questões ambientais, estabelece como diretrizes para garantia de uma gestão ambiental os seguintes objetivos: monitoramento e controle dos impactos causados pelo emprego de sua matéria-prima (toner) como resíduo sólido industrial; destinação de resíduos com fornecedores selecionados; aprimoramento contínuo dos processos e o comprometimento com o atendimento à legislação e normas ambientais aplicáveis; além de ser uma empresa ecologicamente correta, atuando em harmonia com a sociedade e preservando o meio ambiente.

Observa-se em seu processo produtivo a destinação apropriada de todos os resíduos industriais, dentre eles: reutilização da água na limpeza de ambientes; encaminhamento de rejeitos de tinta dos cartuchos às empresas que os reutilizam 
para a produção de outros produtos; coleta seletiva de materiais e doação para a reciclagem em outras empresas; além da reciclagem e reutilização dos papéis usados nos processos de teste dos cartuchos e destinação final adequada às peças e componentes rejeitados ou quebrados no processo produtivo.

Segundo a Ink Press do Brasil, a cada cartucho recondicionado evita-se o consumo de cinco litros de petróleo que são necessários na fabricação de um cartucho novo. A Ink Press é uma das principais fornecedoras de matérias-primas e equipamentos de remanufatura de cartuchos de toner, além de realizar treinamentos nessa área.

Diferentemente do processo de recarga, que consiste apenas na adição de toner, o recondicionamento ou remanufatura de cartuchos contempla as seguintes etapas:

1. Teste de impressão prévio e análise;

2. Abertura do cartucho;

3. Desmontagem das peças;

4. Limpeza de resíduos de toner antigo;

5. Limpeza de contatos;

6. Limpeza de peças;

7. Avaliação das peças e substituição se necessário;

8. Recarga;

9. Remontagem;

10. Teste de impressão final.

Pode-se dizer que o sistema logístico reverso da Tecno Toner utiliza algumas opções da Administração da Recuperação de Produtos ou Product Recovery Management (PRM). O processo produtivo da empresa apresenta principalmente as opções de remanufatura, canibalização e reciclagem.

A empresa agrega valor aos seus produtos por diversos aspectos advindos do emprego da logística reversa, tais como, o respeito à legislação e normas ambientais, não obstante o fato de que tal atitude seja obrigatória, melhora a imagem institucional perante consumidores e clientes; ao reduzir seus custos operacionais em virtude da reutilização ou reaproveitamento das carcaças de cartucho de toner, otimizando o uso de produtos e matérias-primas; como também 
ao investir em seus processos produtivos que proporcionam produtos de alta qualidade de impressão e produtividade.

A seguir um quadro resumo do processo de remanufatura dos cartuchos na Tecno Toner:

\begin{tabular}{|c|c|}
\hline $\begin{array}{l}\text { Nada de improvisos: plástico-bolha e } \\
\text { berços resistentes fazem parte da } \\
\text { embalagem dos toners Tecno Toner. }\end{array}$ & $\begin{array}{l}\text { A qualidade dos cartuchos começa na embalagem. Os } \\
\text { cartuchos de tinta são embalados cuidadosamente. Cada } \\
\text { cartucho de Toner Tecno Toner é, ainda, embalado em } \\
\text { berço resistente, envolvido em espuma de proteção e em } \\
\text { plástico-bolha. Isso garante a integridade do cartucho } \\
\text { durante o transporte e armazenamento. }\end{array}$ \\
\hline $\begin{array}{l}\text { Dentro desse invólucro o cartucho } \\
\text { Tecno Toner fica protegido da luz. }\end{array}$ & $\begin{array}{l}\text { Os cartuchos são acondicionados dentro de plásticos } \\
\text { especiais que impedem a passagem da luz. A luz é nociva } \\
\text { ao cilindro do cartucho, e pode danificá-lo se a peça ficar } \\
\text { exposta a ela por muito tempo. Na embalagem Tecno Toner } \\
\text { esse risco é evitado ao máximo. }\end{array}$ \\
\hline $\begin{array}{l}\text { Algumas das peças que são } \\
\text { normalmente trocadas no } \\
\text { recondicionamento de um cartucho de } \\
\text { toner. }\end{array}$ & $\begin{array}{l}\text { Os cartuchos de toner não são apenas recarregados: são } \\
\text { remanufaturados. Isso significa que eles têm partes de } \\
\text { desgaste trocadas, prevenindo que se quebrem durante o } \\
\text { uso em sua impressora. Um cartucho de toner pode ter } \\
\text { mais de sete peças trocadas. }\end{array}$ \\
\hline $\begin{array}{l}\text { O cilindro de impressão é uma das } \\
\text { peças mais importantes do cartucho e } \\
\text { também a que mais sofre desgastes } \\
\text { durante sua vida útil. }\end{array}$ & $\begin{array}{l}\text { É por esse motivo que a Tecno Toner substitui o cilindro } \\
\text { fotocondutor durante o processo de remanufatura. O cilindro } \\
\text { (da marca Fuji Eletric) utilizado é } 100 \% \text { novo e totalmente } \\
\text { compatível com o modelo do cartucho. }\end{array}$ \\
\hline $\begin{array}{l}\text { A Tecno Toner mantém amplo e variado } \\
\text { estoque de tintas e toners importados } \\
\text { para atender cada tipo de cartucho. }\end{array}$ & $\begin{array}{l}\text { Cada tipo de cartucho exige um tipo de tinta ou toner } \\
\text { específico. O uso de tinta ou toner inadequado pode criar } \\
\text { problemas como impressão fraca, diferenças de tonalidade, } \\
\text { etc. A variedade e a qualidade das tintas e dos toners } \\
\text { importados que a Tecno Toner usa é uma das garantias da } \\
\text { produtividade, segurança e qualidade dos seus produtos. }\end{array}$ \\
\hline
\end{tabular}




\begin{tabular}{|c|c|}
\hline $\begin{array}{l}\text { um cartucho } \\
\text { um produto } \\
\text { dicionado. }\end{array}$ & $\begin{array}{l}\text { Antes de colocar um produto no mercado, a Tecno Toner } \\
\text { recebe de seus fornecedores (dos Estados Unidos e } \\
\text { Europa) matéria-prima específica, material informativo e } \\
\text { manuais sobre o processo de remanufatura e todo o } \\
\text { necessário para se obter um cartucho com as mesmas } \\
\text { características de um produto OEM (original). Todos os } \\
\text { cartuchos Tecno Toner são testados nos laboratórios Tecno } \\
\text { Toner e só depois de sua aprovação é que são liberados } \\
\text { para venda. }\end{array}$ \\
\hline $\begin{array}{l}\text { Pelo ID, a Tecno Toner controla a } \\
\text { qualidade de cada cartucho. }\end{array}$ & $\begin{array}{l}\text { A Tecno Toner acompanha os cartuchos que passam pelo } \\
\text { seu processo industrial, recebendo cada qual um número de } \\
\text { identificação (ID). Através desse acompanhamento, a Tecno } \\
\text { Toner supervisiona e testa a qualidade de cada cartucho - } \\
\text { um a um, criteriosamente. É por isso que a Tecno Toner } \\
\text { pode garantir sua qualidade. }\end{array}$ \\
\hline
\end{tabular}

Quadro 3: Resumo do processo de remanufatura dos cartuchos na Tecno Toner. Fonte: http://www.tecnotoner.com.br/qualidade.jsp Acesso em: 18 set. 2010

Levantamento de preços realizado pelo Banco do Brasil revela que, em média, o custo de aquisição de um cartucho de toner recondicionado representa $20 \%$ do valor de um cartucho original, conforme demonstrado no gráfico a seguir:

\section{Comparação de preços dos cartuchos}

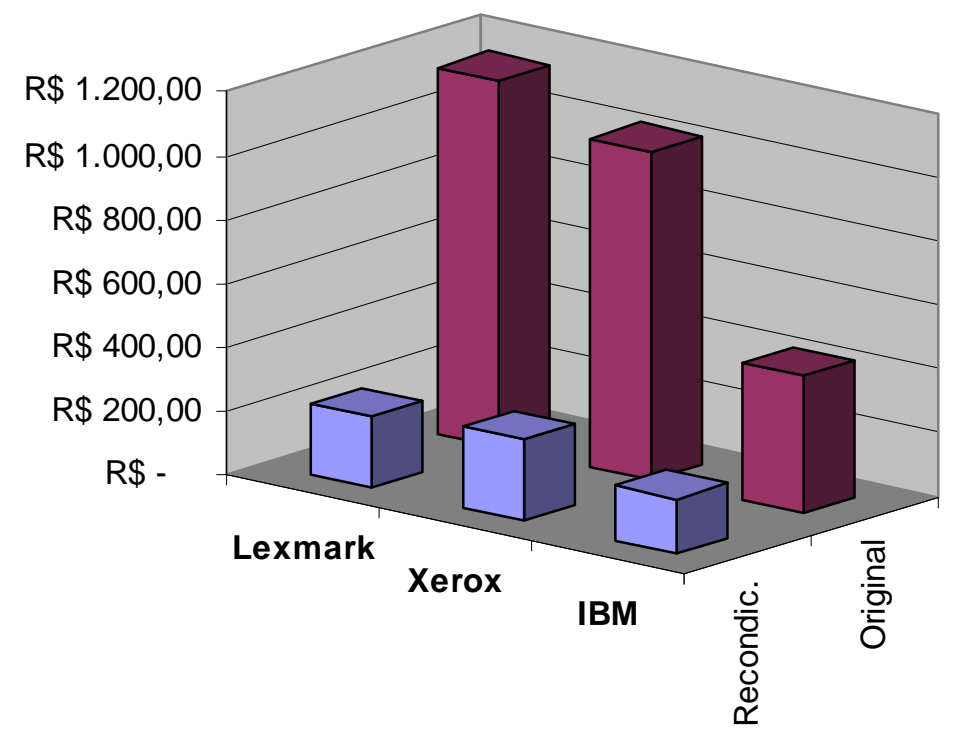

$\square$ Recondic

Gráfico 1: Preços dos cartuchos recondicionados $X$ originais.

Fonte: Banco do Brasil S. A. - Diretoria de Logística, 2003. 
Apesar da grande diferença de preço, não há redução de desempenho e produtividade das impressoras. É importante ressaltar que a empresa Tecno Toner garante seus produtos e atua com enorme sucesso no mercado de recondicionamento de cartuchos desde 1990.

Diante do exposto, pode-se afirmar que a empresa oferece produtos de baixo custo e que proporcionam alta qualidade de impressão e produtividade, além de não prejudicar ou causar danos ao meio ambiente, haja vista que é realizado pela Tecno Toner a destinação final adequada de seus resíduos industriais.

Vale destacar também que o processo de recondicionamento dos cartuchos reduz 0 consumo de energia, por tornar desnecessário a fabricação de um cartucho novo, ou seja, evita-se o gasto de petróleo que seria utilizado no processo produtivo ou confecção desse material. 


\section{CONCLUSÕES E RECOMENDAÇÕES}

Crescimento populacional, industrialização e constantes inovações tecnológicas, todos esses fatores têm contribuído para o descarte cada vez maior de resíduos sólidos que, por sua vez, ocasionam degradação do meio ambiente, constatada pelos vários fenômenos naturais extremos, decorrentes de mudanças climáticas, tais como: calor excessivo, chuvas torrenciais, vendavais, derretimento das calotas polares, inundações e secas prolongadas.

Preocupada com esses acontecimentos, cresce a cada dia o interesse da sociedade em assuntos relacionados à preservação e conservação do meio ambiente, modificando-se o perfil do consumidor de tal maneira que as empresas viram a necessidade de mudar suas estratégias e sistemas tradicionais.

Essa mudança de comportamento do consumidor passa por maiores níveis de renda e de escolaridade, desenvolvimento tecnológico e facilidade de acesso às informações. Essas transformações sociais, culturais e tecnológicas tornam os indivíduos cada vez mais exigentes em relação à maneira como os produtos são produzidos e, principalmente, como é realizada a destinação final dos produtos pósconsumo.

Além disso, a legislação ambiental, ao longo dos últimos anos, torna-se cada vez mais minuciosa e exigente no que diz respeito ao cumprimento de normas ambientais e padrões administrativos necessários para implantação e operação de suas atividades, aplicando pesadas multas às empresas que não obedecem a essas leis.

Diante do exposto, torna-se fundamental às organizações que desejam manteremse competitivas no mercado, o desenvolvimento de seus sistemas logísticos tradicionais, ampliando-os com a implantação dos fluxos inversos de seus produtos, embalagens ou outros materiais, serviços e informações.

A logística reversa é uma ferramenta gerencial que gera vantagem competitiva às organizações, atuando tanto na melhoria da imagem institucional da empresa perante seus consumidores, não obstante o fato de ser uma exigência legal, como também pela redução de custos operacionais, seja pela reciclagem, reutilização ou 
reaproveitamento de materiais e matérias-primas, seja pela economia de energia e combustíveis ou qualquer outro tipo de insumo.

A presente pesquisa apresentou os conceitos de logística direta e reversa, a evolução desses sistemas, seus fluxos e operações e a administração da recuperação de produtos, a questão ambiental e os aspectos econômico-financeiros, além da definição de reciclagem.

Como elo arrematador do trabalho, descreveu-se o estudo de caso na empresa Tecno Toner Cartuchos para Impressoras, além de demonstrar, por intermédio de ilustrações, um procedimento detalhado do processo de recondicionamento de carcaças de toner. Dessa forma, tornou-se possível obter um melhor entendimento e visualização do contexto pesquisado, unindo teoria e prática, além de somar informações imprescindíveis ao desenvolvimento das ideias.

Verificou-se que, além de cumprimento à legislação e normas ambientais necessárias para a realização de suas atividades operacionais, as ações adotadas pela empresa contribuem de forma significativa para a preservação e conservação do meio ambiente, tais como: a reutilização da maioria das carcaças de toner por infinitas vezes e a destinação final adequada de todos os resíduos industriais, peças e componentes rejeitados ou quebrados.

Outras medidas adotadas pela Tecno Toner comprovam suas diretrizes para garantia de um excelente sistema de gestão ambiental, são elas: reaproveitamento da água na limpeza de ambientes da fábrica, encaminhamento de rejeitos de tinta dos cartuchos a outras empresas especializadas para reutilização e produção de outros produtos, coleta seletiva de materiais e reciclagem e reutilização dos papéis utilizados nos processos de testes dos cartuchos.

Além do respeito ao meio ambiente e a certificação ISO 14001:2004, a empresa possui também o certificado de qualidade ISO 9001:2000. A Tecno Toner é uma das principais empresas no mercado brasileiro na área de remanufatura de cartucho de toner desde 1990, além de atuar na Argentina e nos Estados Unidos. Sendo, portanto, uma organização ecologicamente correta, atuando em harmonia com a sociedade e preservando o meio ambiente, e que comercializa produtos de qualidade e de baixo custo. 
Pretende-se com o presente trabalho estimular ainda mais a consciência ecológica da sociedade e das organizações, para que consumidores reflitam sobre os produtos que adquirem e escolhem, dando preferência àqueles que tenham uma destinação pós-consumo adequada, e as empresas busquem cada vez mais novas formas e métodos de gestão e produção em harmonia com o planeta.

Futura pesquisa na área poderia mensurar a totalidade de energia economizada em virtude do processo de fluxo inverso de material. Ou seja, a redução total do consumo de petróleo decorrente da reutilização das carcaças de toner, que torna desnecessária a fabricação de um cartucho novo.

Por tratar-se de um assunto surgido há poucas décadas e, portanto, ser relativamente novo e com muita carência literária, espera-se que a pesquisa contribua nessa área, apresentando os motivos para o estudo da logística reversa e seus benefícios para os assuntos relacionados ao meio ambiente e a sociedade. Sendo ainda um instrumento motivador da conscientização ecológica, possibilitando aos consumidores mais informações quanto às conseqüências maléficas ao planeta em decorrência da destinação final inadequada dos produtos.

Para as organizações, pretende-se com o estudo da logística reversa demonstrar os ganhos econômico-financeiros, seja agregando valor aos seus produtos ou identificando formas eficientes para o uso de canais inversos de insumos.

Conclui-se com a apresentação deste trabalho que é perfeitamente possível diminuir os impactos ambientais e obter vantagem econômico-financeira com a política de logística reversa no Brasil. 


\section{REFERÊNCIAS}

ALVES, Carlos A. A Gestão Eficiente dos Resíduos. Porto: Publindústria, 2005.

ANDRADE, E.M.; FERREIRA, A.C.; SANTOS, F.C.A. Tipologia de Sistemas de Logística Reversa Baseada nos Processos de Recuperação de Valor: estudo de três casos empresariais. In: Anais do SIMPOI, São Paulo, Brasil, 2009.

BRONOSKI, M. Estudo preliminar da logística reversa aplicada aos resíduos provenientes do processo produtivo de compensados e aglomerados. Revista Administrare, Curitiba, v. 2, n. 2, jul./dez. 2003.

CARVALHO, José Crespo de. Logística. 3ํㅡㄹ ed. Lisboa: Edições Sílabo, 2002.

2003. . Logística, Supply Chain \& Network Management. Lisboa: Ad litteram, e-business \& e-commerce. Lisboa: Edições Silabo, 2001.

COUNCIL OF SUPPLY CHAIN MANAGEMENT PROFESSIONALS. In: WIKIPÉDIA, a enciclopédia livre. Flórida: Wikimedia Foundation, 2010. Disponível em: $<$ http://pt.wikipedia.org/w/index.php?title=Council of Supply Chain Management Professionals\&oldid=19541792>. Acesso em: 13 jun. 2010.

DIAS, João Carlos Q. Logística Global e Macrologística. Lisboa: Edições Sílabo, 2005.

INK PRESS DO BRASIL. In: Ink Press do Brasil Ltda. São Paulo: Brasil, 2010. Disponível em: <http://www.inkpress.com.br/11Toner.htm>. Acesso em: 07 set. 2010.

GUARNIERI, P.; CHRUSCIACK, D; OLIVEIRA, I.L; HATAKEYAMA, K; SCANDELARI, L. WMS - Warehouse Management System: adaptação proposta para o gerenciamento da logística reversa. Produção, v. 16, n. 1, 2006.

LEITE, Paulo R. Logística reversa: categorias e práticas empresariais em programas implementados no Brasil - um ensaio de categorização. In: ENCONTRO DA ANPAD, 2005. 
Logística reversa: meio ambiente e competitividade. São Paulo:

Prentice Hall, 2003, 250p.

LOGÍSTICA. In: WIKIPÉDIA, a enciclopédia livre. Flórida: Wikimedia Foundation, 2010.

Disponível em:

<http://pt.wikipedia.org/w/index.php?title=Log\%C3\%ADstica\&oldid=21736527>.

Acesso em: 13 jun. 2010.

MOTA, Sílvia. Produção científica da professora Sílvia Mota. Disponível em:

<http://www.silviamota.com.br/>. Acesso em: 19 jun. 2010.

RAZZOLINI FILHO, Edelvino e BERTÉ, Rodrigo. O Reverso da Logística e As Questões Ambientais no Brasil. Curitiba: Ibpex, 2009.

Relatório Brundtland, 1987.

RECICLA MAIS: revista mensal eletrônica. São Paulo: Ed. Cecília Borges, n. 101, mai. 2010

ROGERS, Dale S.; TIBBEN-LEMBKE, Ronald S. - Going backwards: reverse logistics trends and practices. Segurança do trabalho e gestão ambiental. Reno: Reverse Logistics Executive Council, 1998. Disponível em:

<http://www.rlec.org/reverse.pdf>. Acesso em: 14 mai. 2009.

TECNO TONER. In: TECNO TONER Cartuchos para Impressoras. São Paulo:

Brasil, 2010. Disponível em: <http://www.tecnotoner.com.br/>. Acesso em: 18 set. 2010.

ZANELLA, L. C. H. Metodologia da pesquisa. Apostila elaborada para o curso de administração na modalidade a distância. Brasília: UnB, 2006. 


\section{Anexo A - Estudo de Caso na Empresa Tecno Toner}

A Tecno Toner Cartuchos para Impressoras Ltda, empresa brasileira fundada em 1990, atua na área de recondicionamento e comércio de cartuchos para impressoras a laser e a jato de tinta, com certificações de qualidade e respeito ao meio ambiente (ISO 9001:2000 e ISO 14001:2004).

O processo de remanufatura concentra-se em cartuchos de toner, com mais de 95\% de sua produção. Possui prédio próprio, com toda a estrutura para comportar uma indústria do seu segmento e as pessoas que nela trabalham.

A empresa adotou o método administrativo "10S", que consiste numa ampliação e desenvolvimento do programa "5S" surgido no Japão na década de 1950. Dessa forma, a Tecno Toner busca nessa ferramenta administrativa a implantação da qualidade, organização e otimização dos seus recursos.

A adaptação para o português dos conceitos japoneses originários dos $10 \mathrm{~S}$ foram traduzidos da seguinte forma:

> SEIRI - Senso de Organização, Descarte;

> SEITON - Senso de Ordem, Arrumação;

> SEISO - Senso de Limpeza;

$>$ SEIKETSU - Senso de Saúde;

> SHITSUKE - Senso de Disciplina;

> SETSUYAKU - Senso de Economia;

> SHIKARI YARO - Senso de Determinação;

> SHIDO - Senso de Educação, Treinamento;

> SHISEIRRINRI - Senso de Princípios Morais e Éticos;

> SEKININ SHAKAI - Senso de Responsabilidade Social. 


\section{Coleta das Carcaças, Processo de Recondicionamento e Controle Produtivo}

A coleta das carcaças usadas de cartucho de toner é realizada das seguintes formas:

> Parte da clientela estoca em suas empresas as carcaças usadas até a formação de um lote considerável. Quando isso ocorre, a Tecno Toner é acionada e agenda a coleta das carcaças nesses locais, com carro próprio ou de terceiros;

$>$ Outros clientes enviam as carcaças diretamente a Tecno Toner, seja por transportadora contratada ou pelos Correios;

$>$ Em alguns casos, a coleta das carcaças é realizada quando da entrega de um pedido ao cliente. Nessas situações, não há a necessidade de a quantidade coletada (carcaças usadas) ser a mesma quantidade que foi remanufatura e entregue conforme o pedido realizado pelo cliente.

Todo material coletado passa por avaliação. Após esse processo, separam-se as carcaças que serão reutilizadas no processo produtivo das que serão sucateadas. $O$ material sucateado é destinado às empresas que fazem a sua destinação correta.

Após o encerramento do processo de triagem, os clientes são informados, por meio de relatórios, das quantidades de resíduos gerados pelo material coletado.

A Tecno Toner investe em processos de produção e de controle da sua qualidade industrial com o objetivo de fornecer produtos com garantia contra defeitos de fabricação. Dessa forma, os cartuchos Tecno Toner não são simplesmente recarregados, eles são recondicionados (remanufaturados), haja vista que o uso de um cartucho sempre gera desgaste natural em suas peças.

O processo de remanufatura dos cartuchos Tecno Toner consiste na desmontagem; limpeza; troca de peças defeituosas, danificadas ou gastas e na inserção de toner ou tinta $100 \%$ novos. Assim, a cada remanufatura são substituídas por novas as peças internas que sofrem desgaste durante seu uso, como o cilindro de impressão, o chip eletrônico, fitas de vedação, etc. Cada tipo de cartucho tem seu tipo de toner. A utilização indevida do toner acarreta uma impressão de má qualidade, podendo até danificar a impressora. 
Desde que o casco não se quebre, a carcaça de cartucho de toner é utilizada por infinitas vezes. O percentual de reutilização e aproveitamento é de $100 \%$ para os cartuchos vazios comprados pela Tecno Toner. Para os cartuchos recebidos de sua clientela, por dependerem do local de origem e da maneira como foram acondicionados, o aproveitamento das carcaças pode cair para até $50 \%$. Contudo, a média geral de aproveitamento gira em torno de $85 \%$.

Os cartuchos Tecno Toner possuem um número de identificação (ID) que permite o completo acompanhamento do cartucho no seu processo de produção e venda, antecipando-se, inclusive, a possíveis problemas no cartucho. Através desse acompanhamento, a Tecno Toner supervisiona, testa e garante a qualidade de cada produto, controlando criteriosamente sua qualidade.

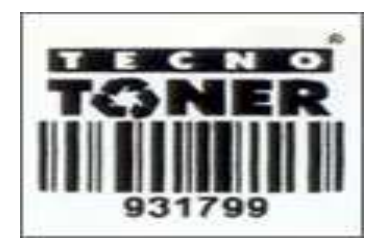

Figura 4: Etiqueta ID.

Fonte: http://www.tecnotoner.com.br/qualidade.jsp

Acesso em: 18 set. 2010

\section{Política de Qualidade}

Os produtos Tecno Toner tem alta qualidade de impressão e produtividade. Essa qualidade é proporcionada pelo processo de recondicionamento do cartucho. Conforme já mencionado, esse processo não consiste em apenas reabastecer o cartucho com toner.

A seguir algumas informações básicas para identificar se o cartucho foi recondicionado ou apenas reabastecido. Atentar que a qualidade da impressão pode variar também de acordo com o estado da impressora e do cartucho usado:

$>$ A impressão de boa qualidade é uniforme e regular em toda sua extensão. A impressão de má qualidade apresenta manchas, irregularidades e falhas;

$>$ A impressão de má qualidade apresenta falhas nos textos, com letras borradas e/ou cortadas, linhas incompletas e manchas; 
> A boa impressão é resistente ao toque. A impressão de má qualidade não funde completamente o toner. Basta passar os dedos para soltá-la do papel.

Os cartuchos Tecno Toner são recondicionados e testados um a um para garantir impressões perfeitas, resistentes e sem manchas e irregularidades, permitindo uso constante, sem desgaste anormal da impressora.

\section{Política Ambiental}

A Tecno Toner busca diretrizes para garantia de um sistema de gestão ambiental. Os principais objetivos dessa gestão são:

> Monitoramento e controle do principal impacto causado pelo uso de sua matéria-prima (toner) como resíduos sólidos industriais, e outros resíduos não agravantes através de reciclagem;

> Destinação de resíduos com fornecedores selecionados;

> Aprimoramento contínuo dos processos e o comprometimento com o atendimento à legislação e normas ambientais aplicáveis;

> Ser uma empresa ecologicamente correta, atuando em harmonia com a sociedade, preservando o meio ambiente e o ser humano;

$>$ Consciência ecológica.

A Tecno Toner possui as licenças ambientais necessárias para seu funcionamento e segue as determinações legais para operar respeitando o meio ambiente. São licenças ambientais obrigatórias de acordo com a legislação expressa no artigo 58 do Regulamento da Lei № 997/76, aprovado pelo Decreto ํㅜ 8468/76 e alterado pelo Decreto ํo 47397/02.

A empresa possui também o CADRI - Certificado de Aprovação para Destinação de Resíduos Industriais. Esse certificado aprova o encaminhamento de resíduos industriais a locais de reprocessamento, armazenamento, tratamento ou disposição final, licenciados e autorizados pela CETESB - Companhia Ambiental do Estado de São Paulo. 
Outras determinações legais observadas pela empresa são: a Lei Federal 9605, de 12 de fevereiro de 1998, e o Decreto Federal 3179, de 22 de dezembro de 1999 (Lei dos Crimes Ambientais), sendo cadastrada junto ao IBAMA - Instituto Brasileiro do Meio Ambiente e dos Recursos Naturais Renováveis, conforme Lei № 6938, Art. 17, incisos I e II.

A Tecno Toner realiza suas atividades operacionais em conformidade com essas Leis e Licenças, dando destinação adequada a todos os seus resíduos industriais, tais como:

> Reutilização da água na limpeza de ambientes industriais - A água utilizada na lavagem das salas de remanufatura é totalmente coletada, filtrada e reutilizada no mesmo processo repetidas vezes. Os resíduos de toner resultantes da filtragem são encaminhados para reutilização como matériaprima de diversos pigmentos;

$>$ Rejeitos de tinta também são descartados com responsabilidade ambiental A tinta retirada dos cartuchos é enviada para empresas que reutilizam o produto também para a confecção de pigmentos;

> Flanelas e luvas: lavados corretamente e reutilizados - São encaminhadas para a empresa ALSCO do Brasil para serem lavadas. A água utilizada na lavagem é tratada e reaproveitada. Todo o material enviado retorna para a Tecno Toner para sua reutilização;

$>$ Papéis reciclados e reutilizados - A Tecno Toner recicla ou reutiliza 98\% do papel utilizado nos processos de teste dos seus cartuchos;

> Coleta seletiva - Todos os ambientes da empresa contam com coleta seletiva de materiais, que são doados para empresas de reciclagem e para a CORBES - Cooperativa de ex-catadores de rua de Salto (SP);

> Sucatas destinadas corretamente - Cartuchos que não passam pela inspeção prévia (rejeitados ou quebrados) são desmontados. O material plástico é extrusado (moído) e são injetados novos cascos. As peças internas do cartucho e seus componentes básicos (metais), que são substituídas a cada remanufatura, são encaminhadas para outras empresas para reciclagem. 
Como ação de responsabilidade social, destaca-se a realização, desde 2006, do Projeto Reciclar que consiste na produção e confecção de cadernos de atividades infantis, com o intuito exclusivo de doá-los a entidades, empresas e escolas.

Os cadernos são fabricados com a reciclagem das folhas utilizadas nos processos de teste dos cartuchos remanufaturados pela Tecno Toner. A cada mês a empresa utiliza cerca de 80 mil folhas de papel sulfite, das quais recicla ou reutiliza $98 \%$. Grande parte desse material que tem condições de reutilização é empregada na produção desses cadernos.

O Projeto Reciclar tem como objetivo beneficiar crianças carentes em idade escolar, como também dar destinação ecologicamente correta a grande parte do papel utilizado na empresa.

Fonte: TECNO TONER. In: TECNO TONER Cartuchos para Impressoras. São Paulo: Brasil, 2010. Disponível em WWW:<URL:http://www.tecnotoner.com.br/>. Acesso em: 18 set. 2010. 


\section{Anexo B - Histórico e Funcionamento das Impressoras a Laser}

Gary Strakweather, empregado da corporação Xerox, inventou a impressora a laser e construiu o primeiro protótipo, que imprimia uma página por minuto com resolução de $500 \mathrm{DPI}$. A Xerox não vislumbrando demanda para o produto, vendeu o projeto para a empresa Cânon, que construiu o primeiro cartucho no ano de 1975. A fabricação da primeira impressora a laser foi em 1983, por Hewlett - Packard e Cânon.

O funcionamento da impressora a laser constitui-se na utilização do raio laser como forma de imprimir uma imagem latente num intermediário, o cilindro fotocondutor orgânico (comumente denominado OPC) e sua posterior transmissão para o papel com o toner através dos seis passos da impressão a laser: descarregamento e carregamento do "OPC"; exposição; revelação; transferência; fusão e limpeza.

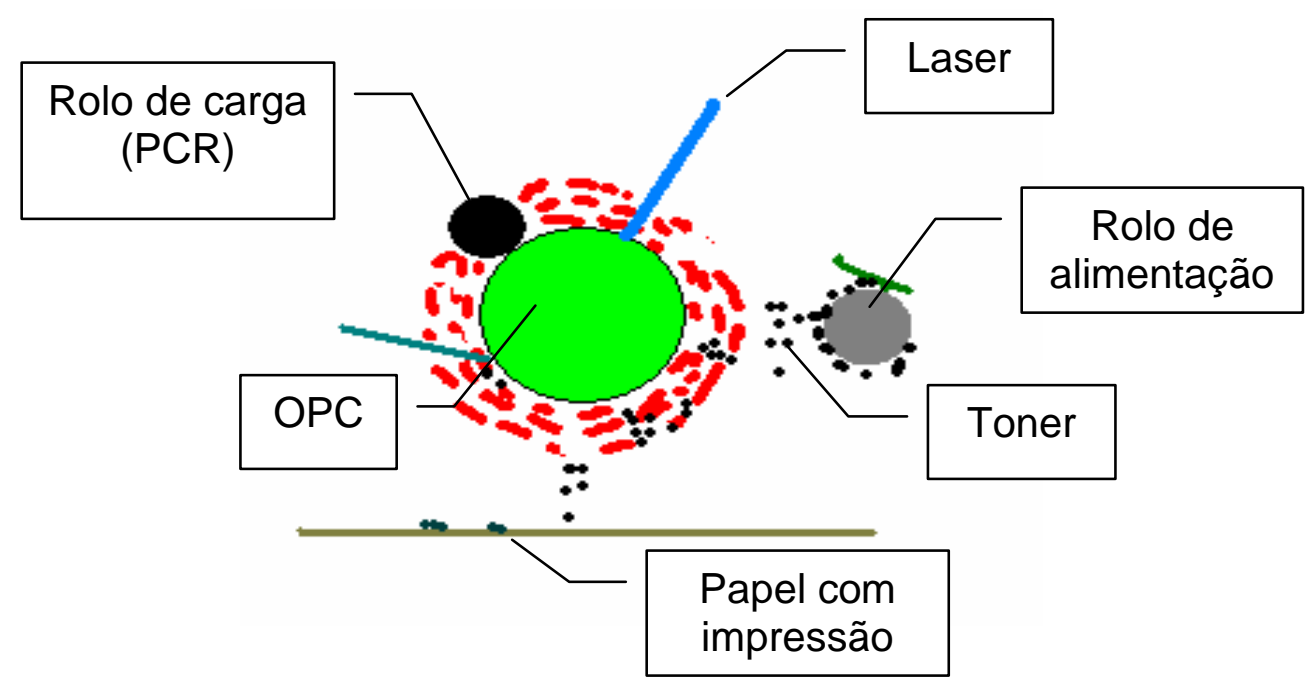

Figura 5: llustração dos seis passos da impressão a laser. http://www.inkpress.com.br/ Acesso em: 18 set. 2010

Fonte: INK PRESS DO BRASIL. In: Ink Press do Brasil Ltda. São Paulo: Brasil, 2010. Disponível em WWW:<URL:http://www.inkpress.com.br/11Toner.htm>. Acesso em: 07 set. 2010. 


\section{Anexo C - Remanufatura do Cartucho HP CE505 A/X}

O presente estudo descreve a seguir o processo de remanufatura do cartucho HP CE505 A/X. Optou-se por esse novo modelo, por apresentar inovações, como laterais rebitadas (sem parafusos) e um tipo de joelho como engrenagem do OPC, que podem dificultar o recondicionamento do cartucho, exigindo-se um cuidado adicional, como a substituição dos rebites por parafusos.

Materiais necessários:

- Alicate de corte pequeno

- Alicate de bico fino

- Alicate mini turquesa

- Chave Philips

- Chave de fenda pequena

- Álcool isopropílico

- Pano livre de fiapos

- Cera polidora

- Pó lubrificante para OPC e lâmina limpadora

- Graxa lubrificante especial para toner

- Graxa condutiva para contatos

- Estação de limpeza de toner ou aspirador específico para toner

- Palitos de madeira

- Algodão

- Removedor de pinos

- Cilindro ótico (opcional)

- Lâminas de limpeza e de dosagem (opcionais)

- Pó específico 
- Chip específico para cada carcaça (05A e 05X)

- Broca e furadeira

- Estilete

- 3 parafusos para toner

A seguir o processo de recondicionamento do novo cartucho HP CE505 A/X:

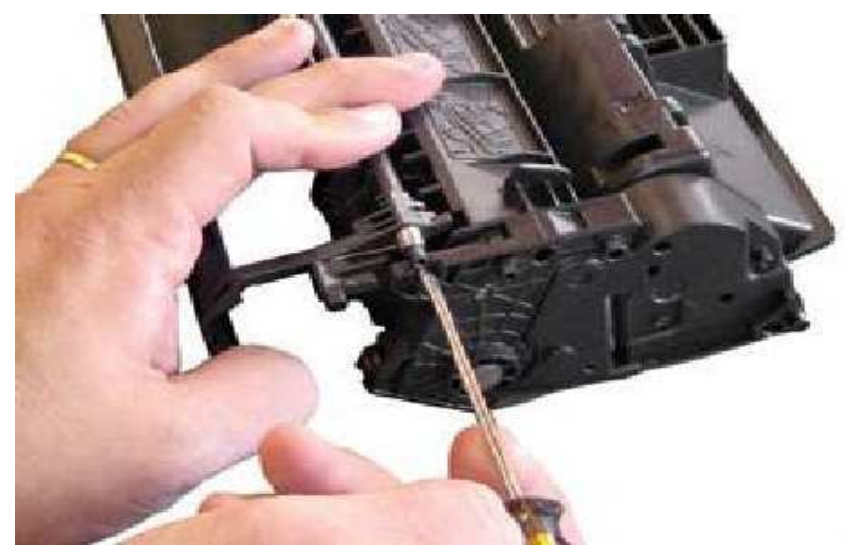

Figura 6: Retirada do protetor do OPC.

Fonte: http://www.reciclamais.com/pt/revista/edicoes-online Acesso em: 07 set. 2010
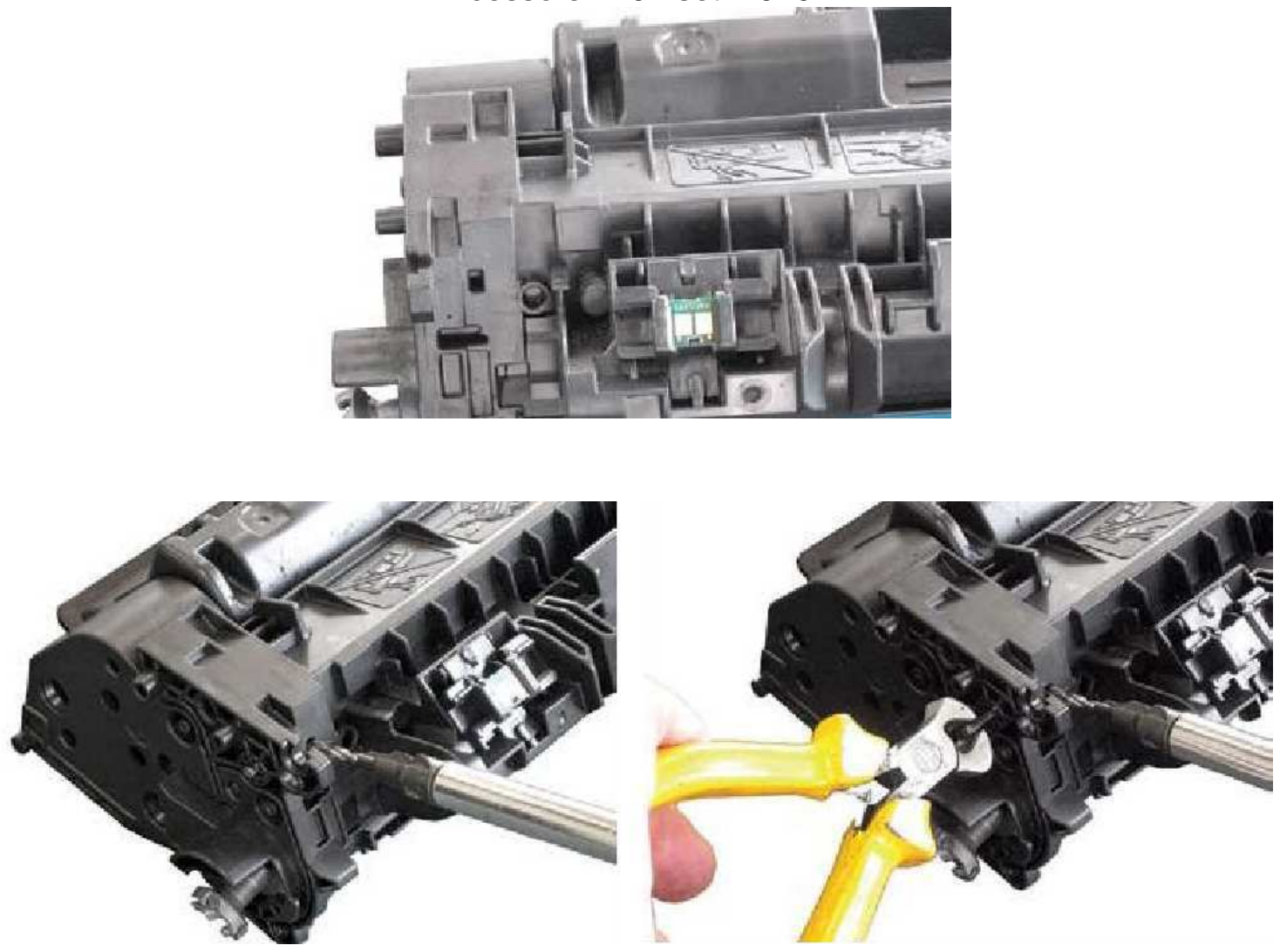

Figuras 7, 8 e 9: Sequência de retirada do pino do lado esquerdo. Fonte: http://www.reciclamais.com/pt/revista/edicoes-online Acesso em: 07 set. 2010 

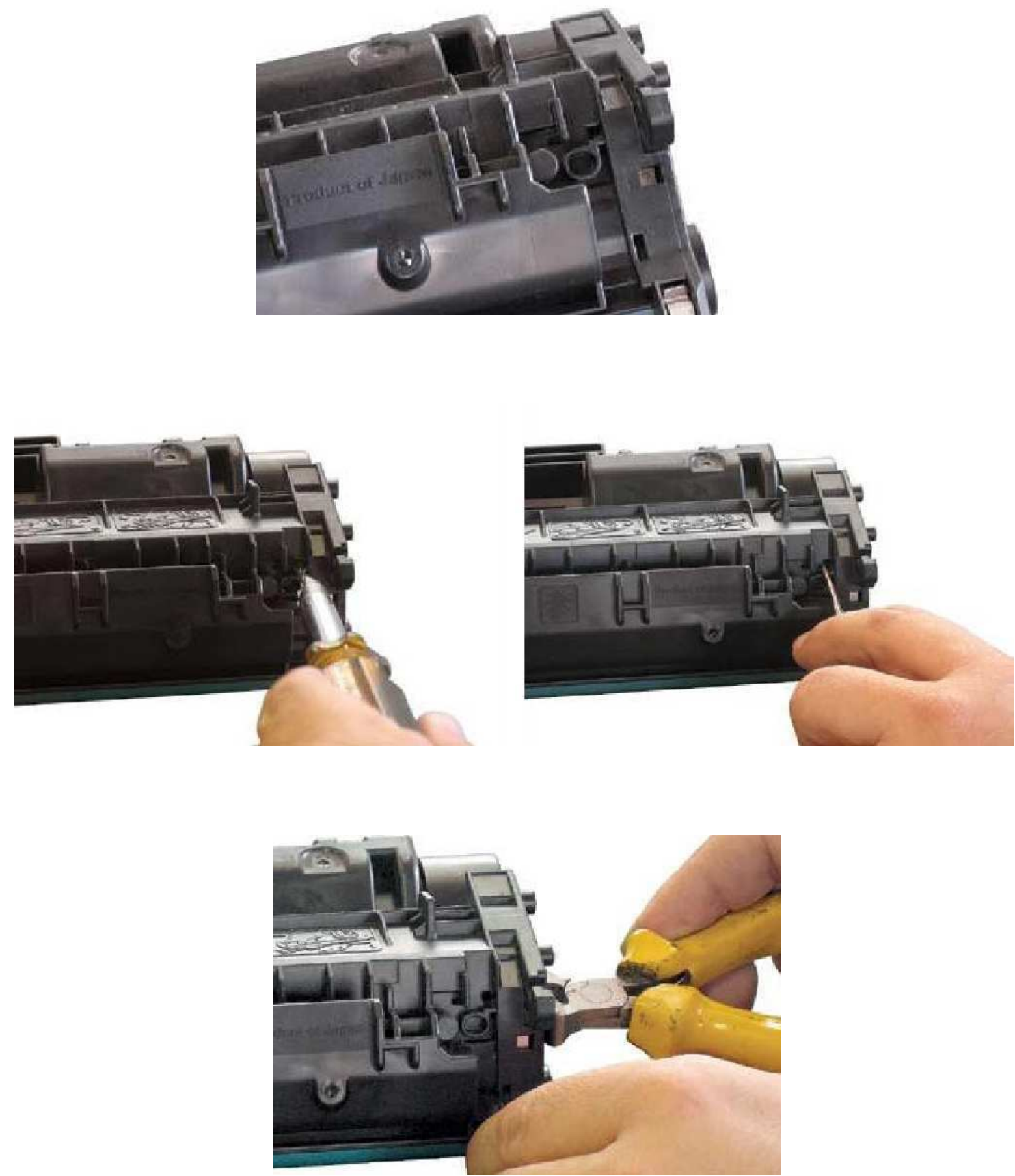

Figuras 10, 11, 12 e 13: Sequência de retirada do pino do lado direito Fonte: http://www.reciclamais.com/pt/revista/edicoes-online Acesso em: 07 set. 2010 


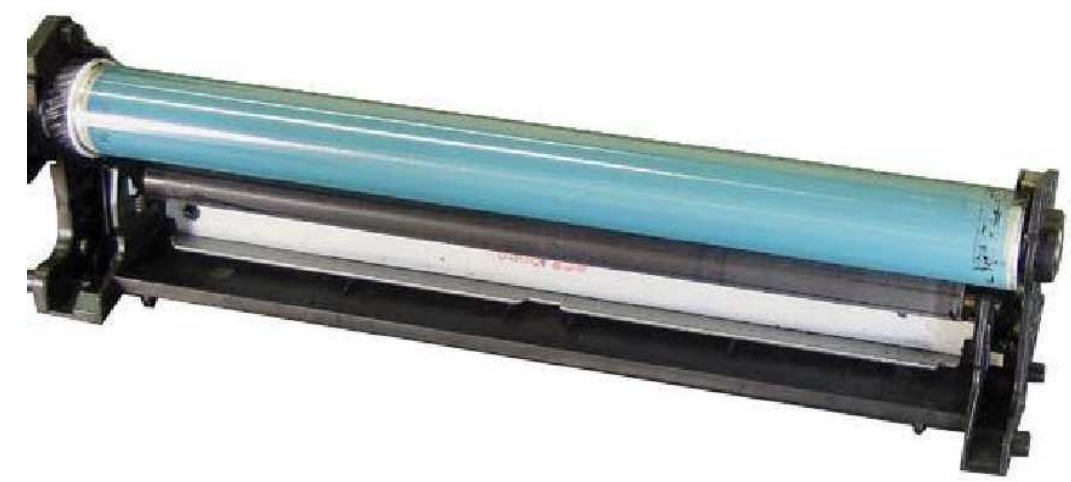

Figura 14: Seção de lixo

Fonte: http://www.reciclamais.com/pt/revista/edicoes-online Acesso em: 07 set. 2010

Separar as duas partes:
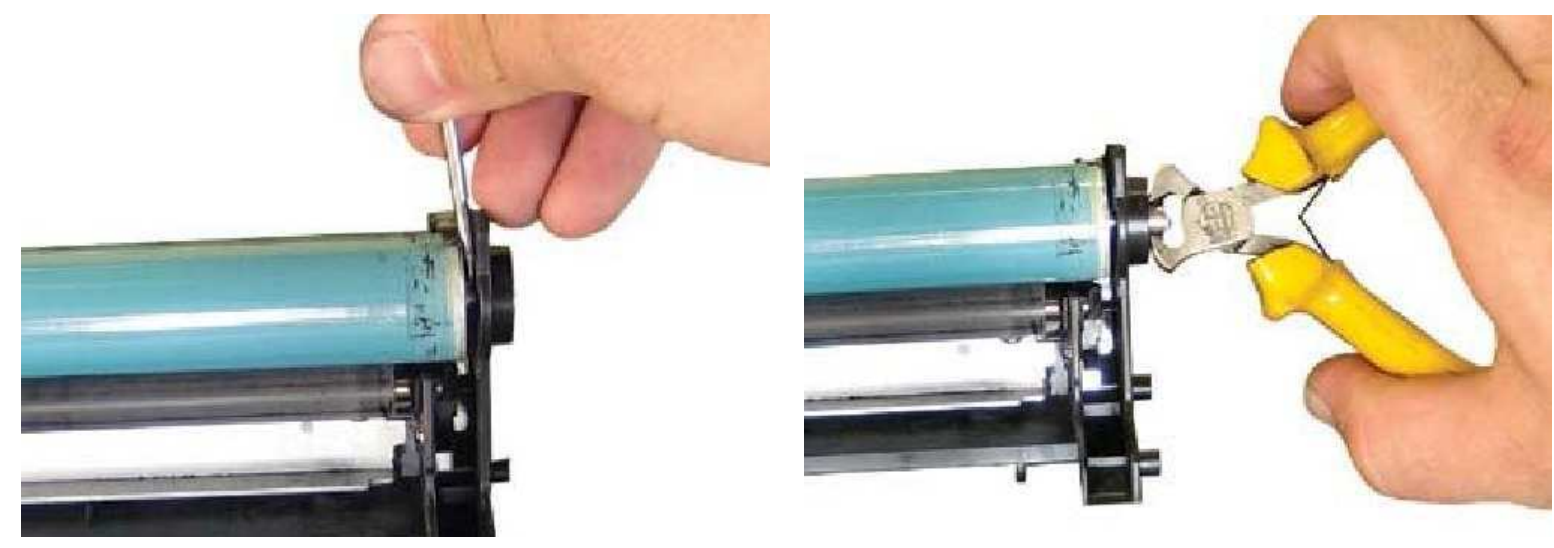

Figuras 15 e 16: Retirada do pino de aterramento do OPC Fonte: http://www.reciclamais.com/pt/revista/edicoes-online Acesso em: 07 set. 2010

Retirar o OPC, inspecionar e substituí-lo, se necessário. Atentar para o limitador do OPC, o qual existe para fazer com que o OPC não se movimente horizontalmente, não podendo ser danificado.

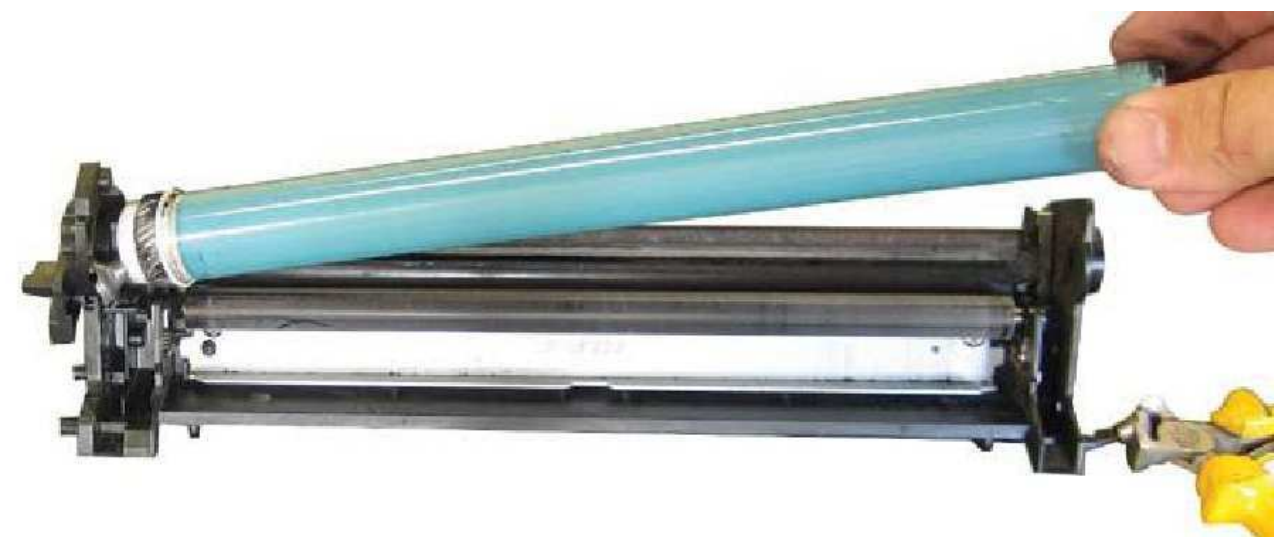

Figura 17: Retirada do OPC

Fonte: http://www.reciclamais.com/pt/revista/edicoes-online Acesso em: 07 set. 2010 
Retirar o PCR com o auxílio de um alicate de bico. Inspecionar e substituí-lo, se necessário.

Retirar a lâmina de limpeza. Inspecionar e substituí-la, se necessário.

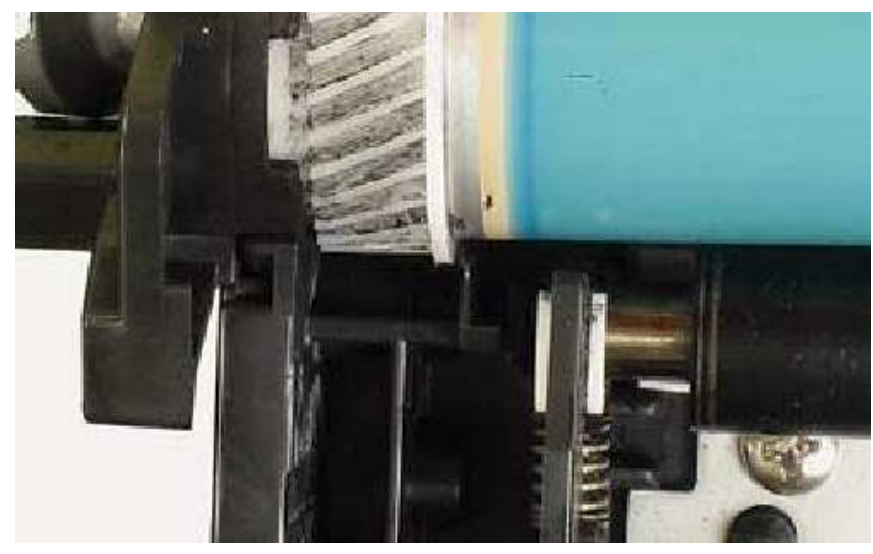

Figura 18: Detalhe do limitador de curso do OPC.

Fonte: http://www.reciclamais.com/pt/revista/edicoes-online Acesso em: 07 set. 2010

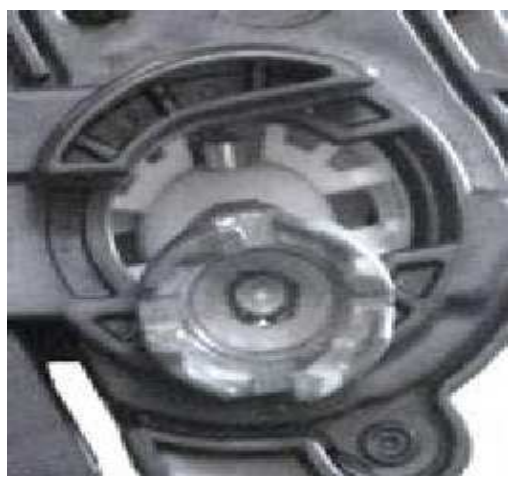

Figura 19: Detalhe da nova engrenagem do OPC.

Fonte: http://www.reciclamais.com/pt/revista/edicoes-online Acesso em: 07 set. 2010

Limpar com ar comprimido ou com aspirador autorizado para toner a seção de lixo.

Inspecionar as espumas das laterais do berço da limpadora. Ver também a espuma localizada abaixo da mesma lâmina.

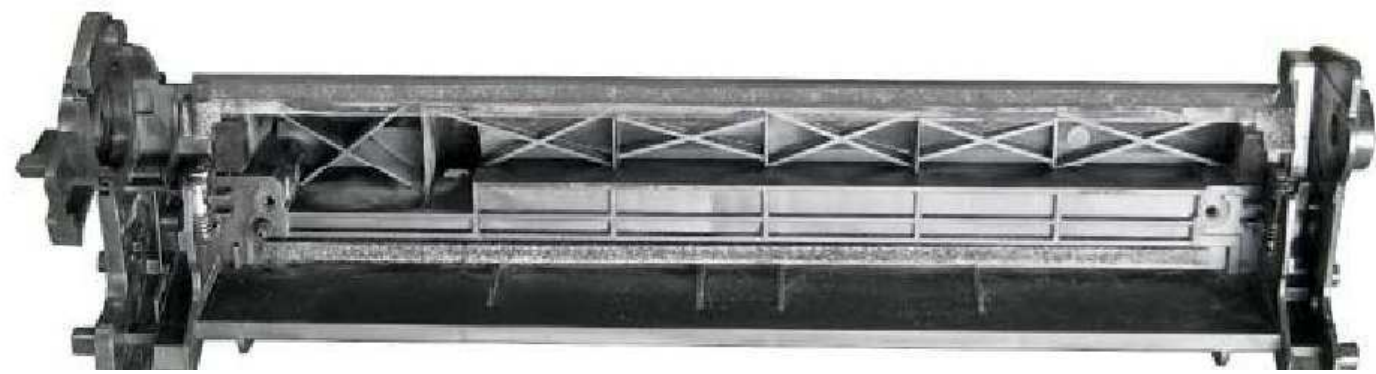

Figura 20: Seção de lixo

Fonte: http://www.reciclamais.com/pt/revista/edicoes-online Acesso em: 07 set. 2010 
Inspecionar a lâmina de recuperação e procurar por qualquer indício de deslocamento, amassados ou algo que possa prejudicar sua eficiência.

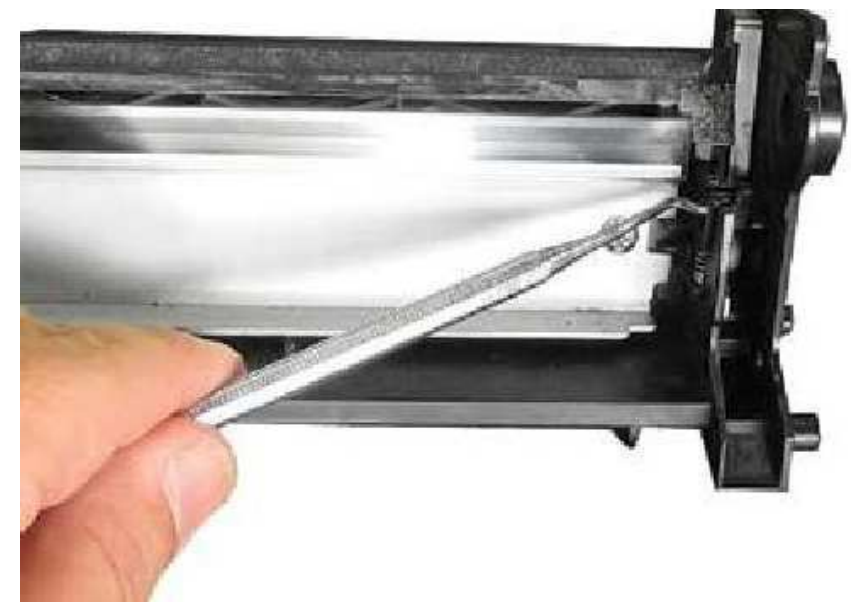

Figura 21: Inspeção da lâmina de recuperação Fonte: http://www.reciclamais.com/pt/revista/edicoes-online Acesso em: 07 set. 2010

Inspecionar, limpar e passar graxa condutiva no contato do PCR e no contato do OPC.

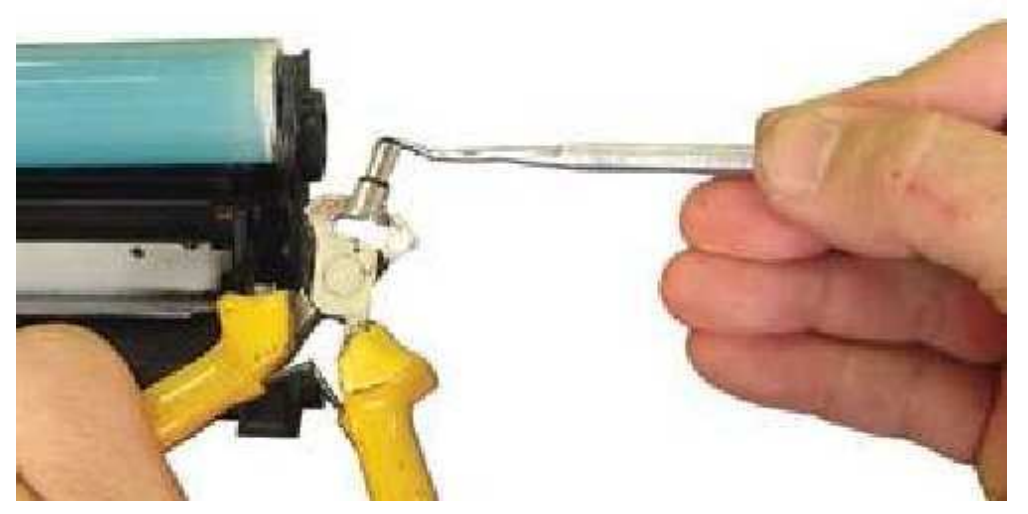

Figura 22: Lubrificações na seção de lixo: Esquerda, PCR e Direita, pino de aterramento do OPC

Fonte: http://www.reciclamais.com/pt/revista/edicoes-online Acesso em: 07 set. 2010

Passar pó lubrificante no OPC e reservá-lo.

Remontar a lâmina limpadora, o PCR, o OPC e reservar esta seção.

Após os passos anteriores, ir para a seção do pó. 


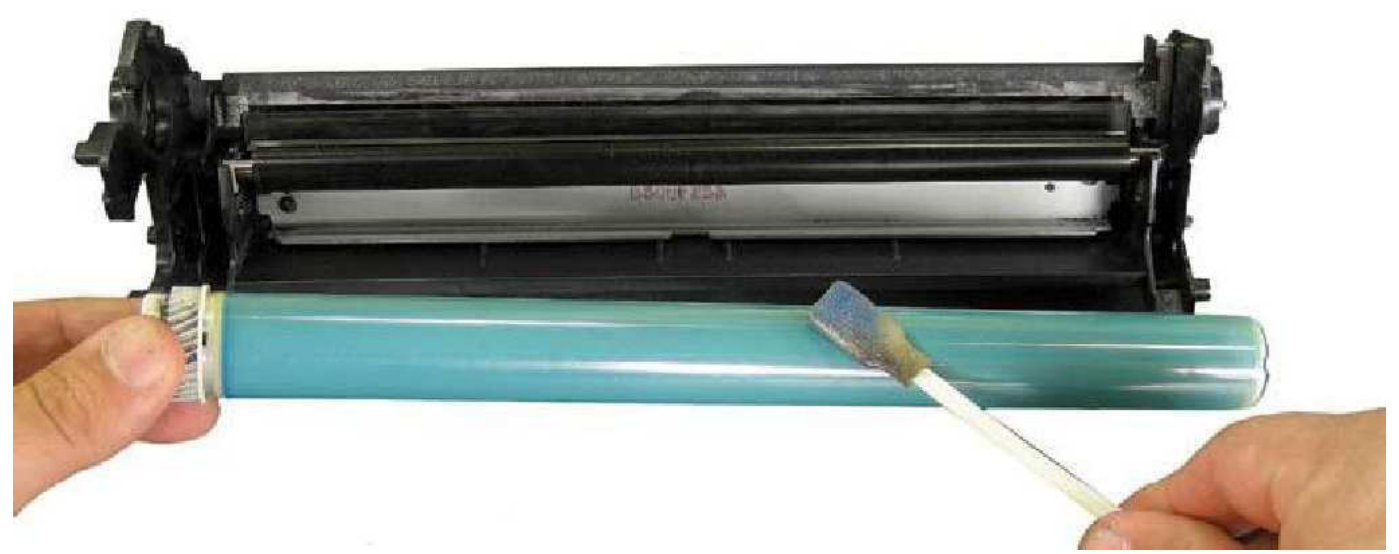

Figura 23: Lubrificação do OPC

Fonte: http://www.reciclamais.com/pt/revista/edicoes-online Acesso em: 07 set. 2010
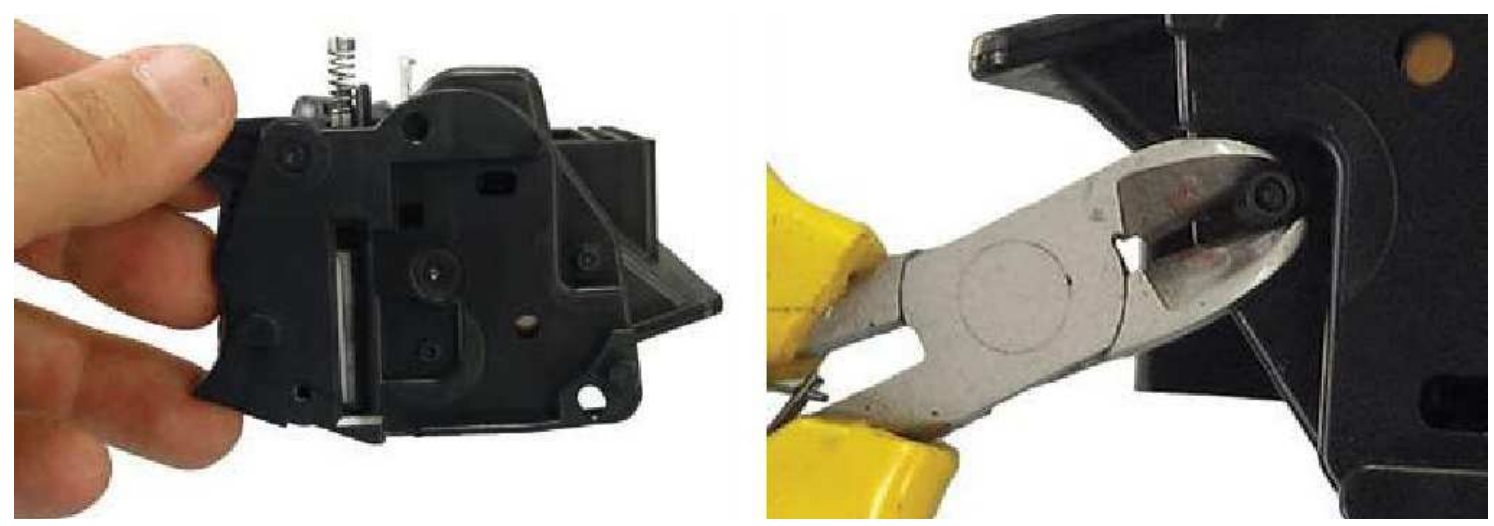

Figuras 24 e 25: Lateral rebitada do contato do magnético (oposta às engrenagens) e a retirada do rebite.

Fonte: http://www.reciclamais.com/pt/revista/edicoes-online Acesso em: 07 set. 2010

Ambas as laterais do cartucho são rebitadas, contudo, trabalhar apenas na lateral do contato elétrico.

Cortar os rebites da lateral dos contatos com muita atenção.

Utilizar uma broca fina para furar os locais dos rebites. 

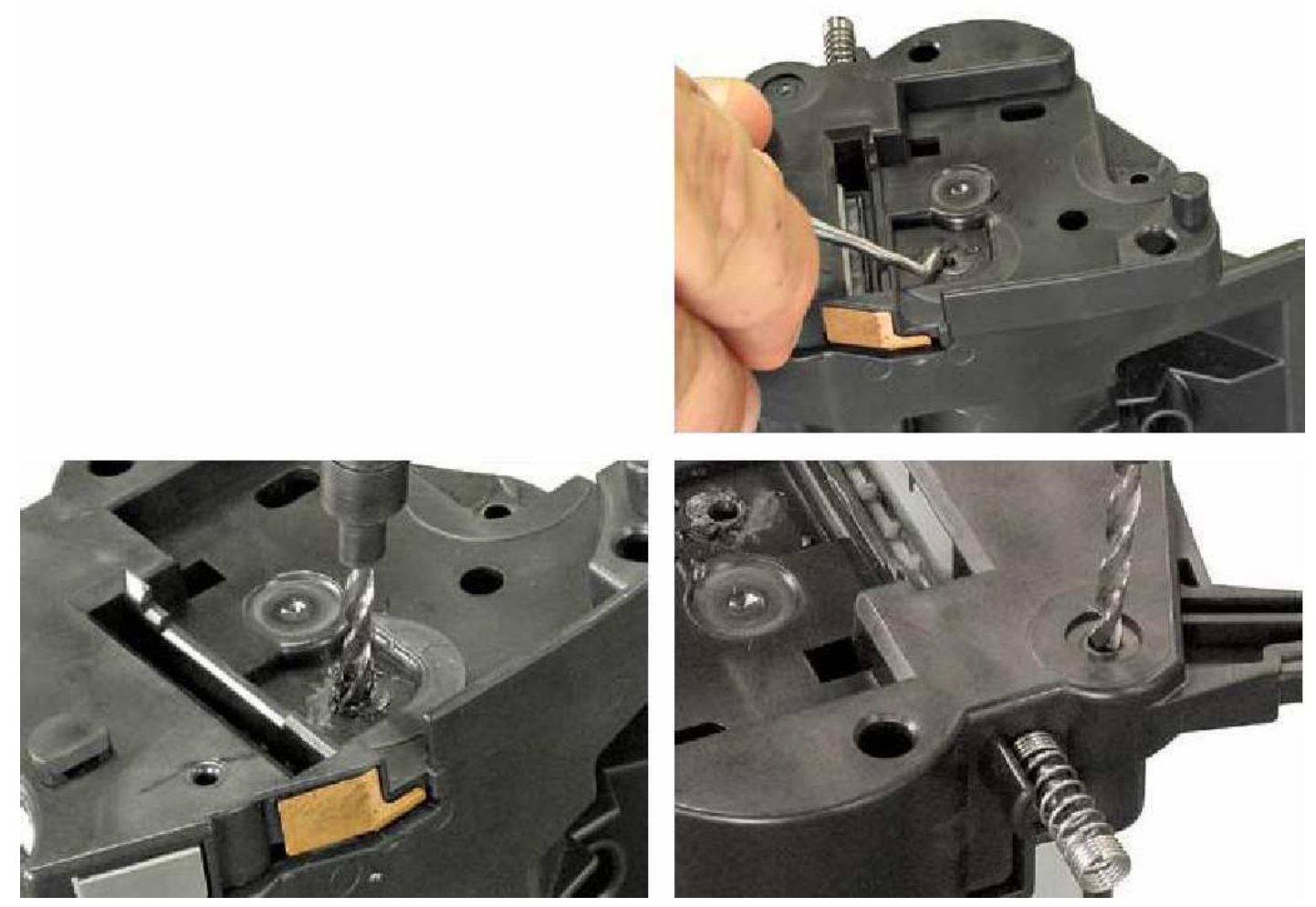

Figuras 26, 27 e 28: Sequência de furos dos rebites da lateral. Fonte: http://www.reciclamais.com/pt/revista/edicoes-online Acesso em: 07 set. 2010

Utilizar uma chave de fenda fina para forçar com cautela a quebra do pino interno. Observar que o estabilizador continuará preso na lateral.

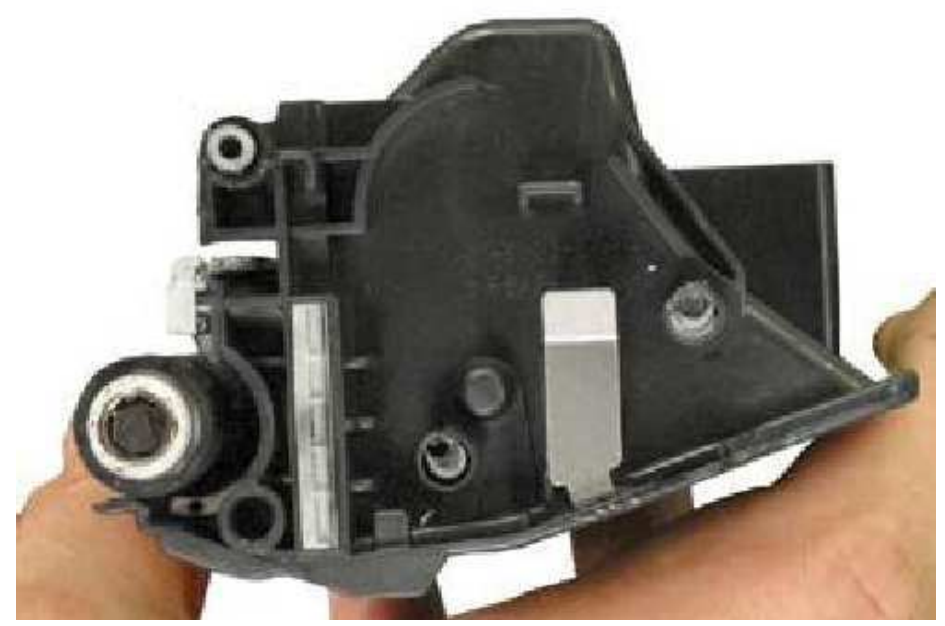

Figura 29: Parte interna da lateral.

Fonte: http://www.reciclamais.com/pt/revista/edicoes-online Acesso em: 07 set. 2010 
Retirar o magnético com muita atenção para não perder as buchas, a engrenagem do rolo e a pequena peça em forma de " $C$ " existente no estabilizador perto das molas.

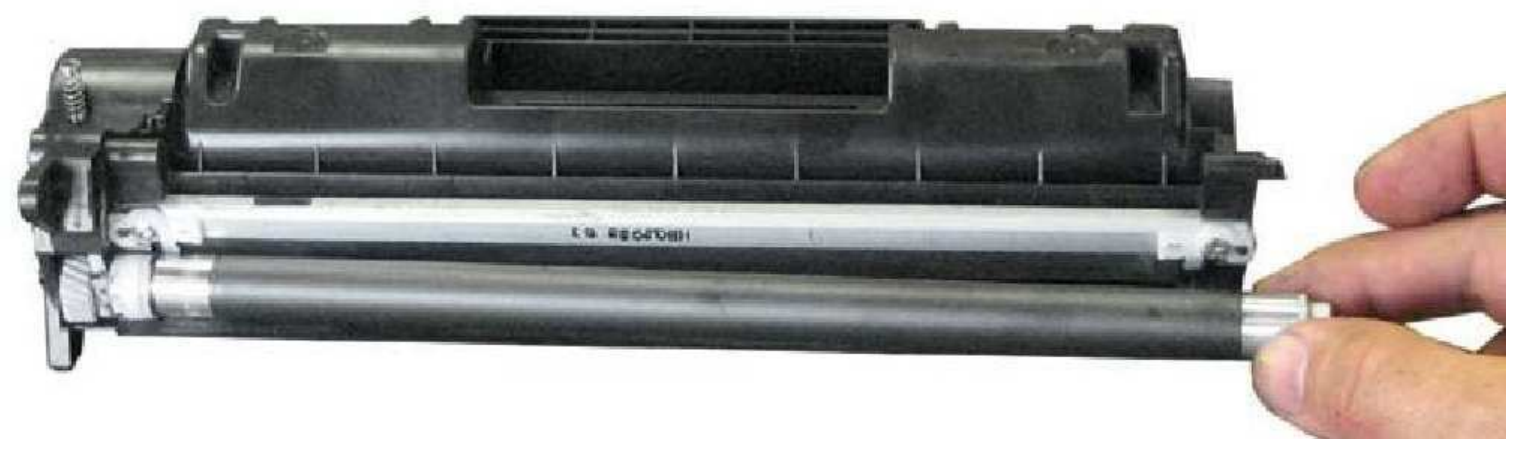

Figura 30: Retirada do magnético.

Fonte: http://www.reciclamais.com/pt/revista/edicoes-online Acesso em: 07 set. 2010

Limpar e inspecionar o magnético, procurando por qualquer indício de defeitos ou riscos em sua superfície, substituindo-o caso necessário.

Limpar e inspecionar as buchas do rolo magnético, substituindo-as caso estejam danificadas.

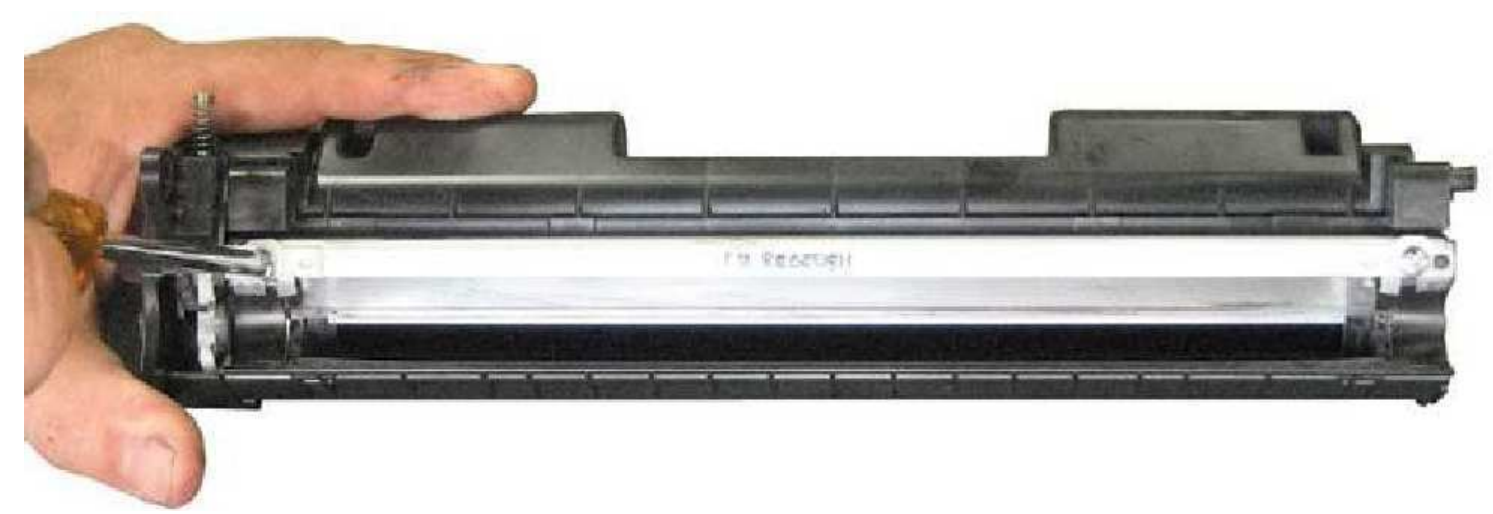

Figura 31: Retirada da dosadora.

Fonte: http://www.reciclamais.com/pt/revista/edicoes-online Acesso em: 07 set. 2010

Desparafusar a lâmina dosadora, limpando e inspecionando-a, procurando eventuais falhas, trincas, escurecimento ou empenamento, substituindo-a caso necessário. 

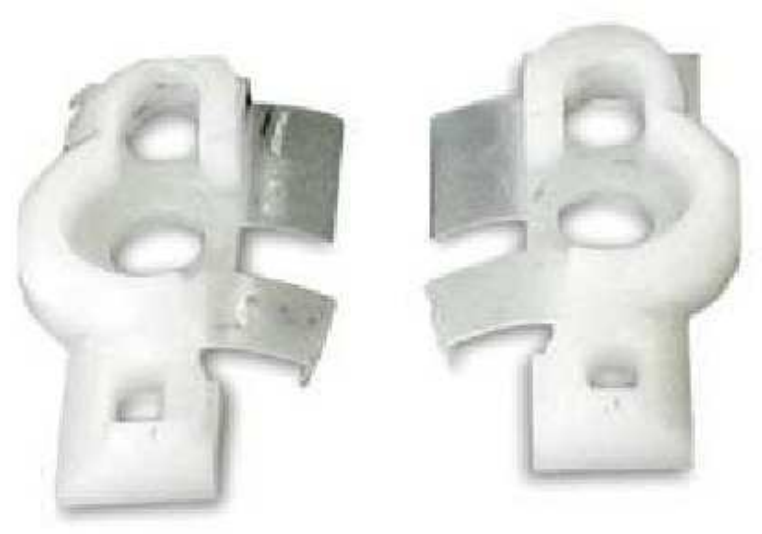

Figura 32: Detalhe dos limpadores do magnético, localizados acima da dosadora. Fonte: http://www.reciclamais.com/pt/revista/edicoes-online Acesso em: 07 set. 2010

Atentar para as duas pequenas linguetas posicionadas acima da lâmina dosadora, substituindo-as caso alguma esteja danificada.

Limpar com álcool isopropílico e passar graxa condutiva no contato do rolo magnético.

Inspecionar as espumas de vedação da Lâmina de dosagem.

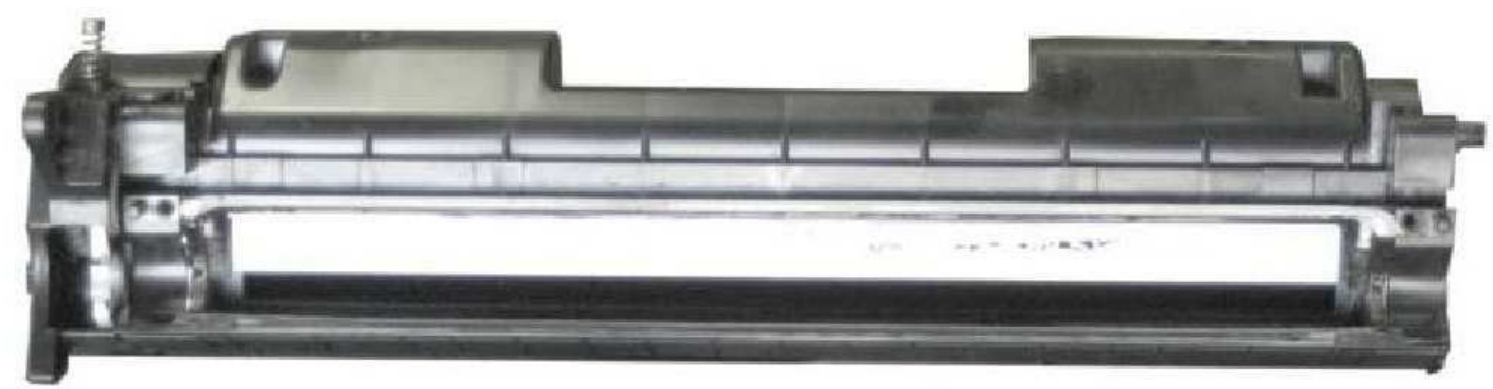

Figura 33: Seção de pó (mostra da vedação por trás da dosadora).

Fonte: http://www.reciclamais.com/pt/revista/edicoes-online Acesso em: 07 set. 2010

A colocação do pó pode ser feita de duas maneiras: quando há a necessidade de utilização de lacre e para as situações onde não há a utilização de lacre. Nesta apresentação será demonstrada apenas a situação onde não serão utilizados os selos. 


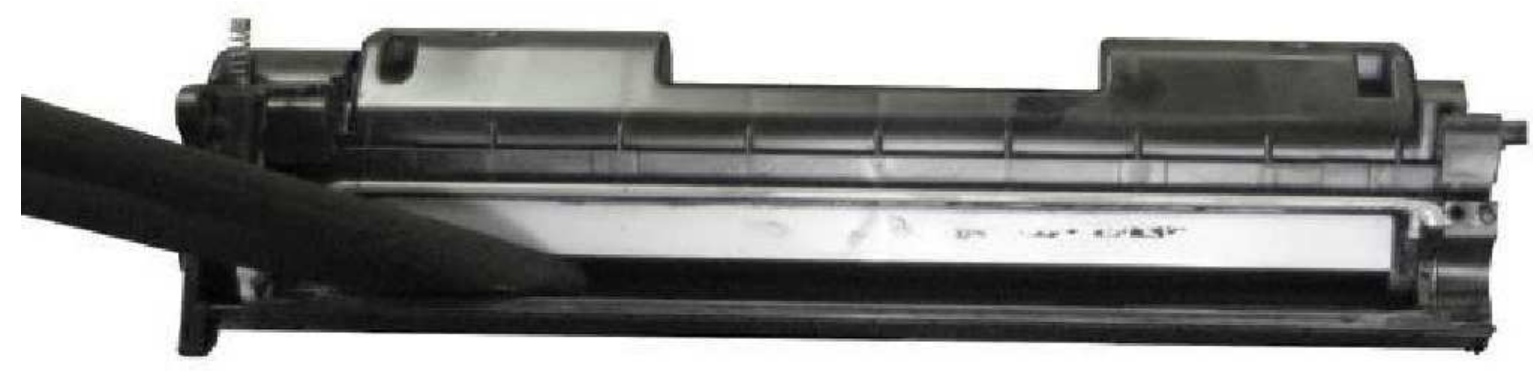

Figura 34: Aspiração do restante do pó.

Fonte: http://www.reciclamais.com/pt/revista/edicoes-online Acesso em: 07 set. 2010

Realizar uma limpeza cuidadosa na seção de pó, eliminando qualquer indício de pó antigo.

Colocar pó na fenda da lâmina dosadora.

Reinstalar a lâmina dosadora e as linguetas acima da mesma.

Lubrificar com graxa condutiva o contato da mola do rolo magnético.

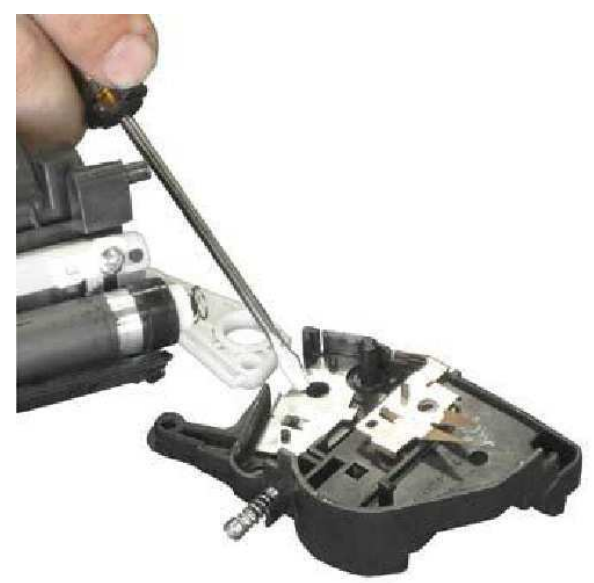

Figura 35: Lubrificação do contato do magnético.

Fonte: http://www.reciclamais.com/pt/revista/edicoes-online Acesso em: 07 set. 2010

Reinstalar o rolo magnético, atentando para não esquecer as buchas e a engrenagem. Tomar cuidado ao instalar o chanfro do núcleo do magnético na carcaça. 


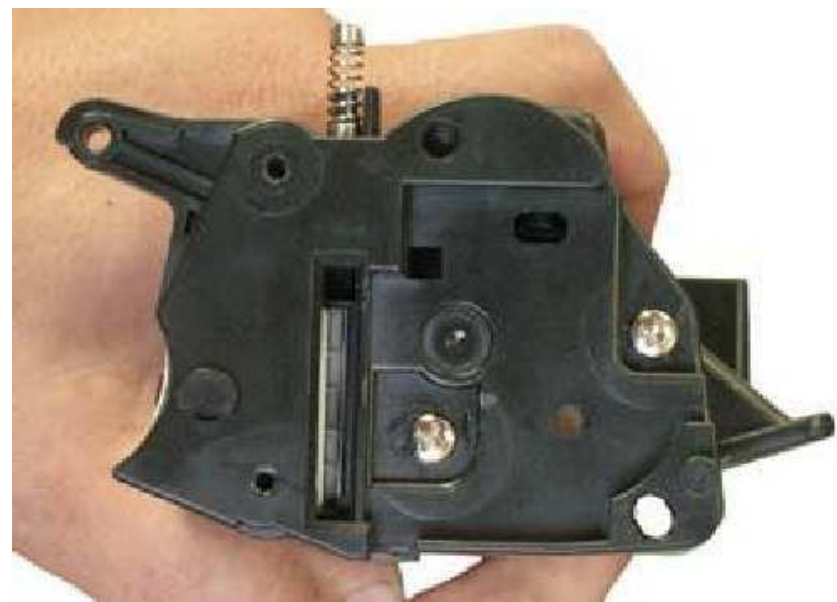

Figura 36: Detalhe dos parafusos já instalados na lateral. Fonte: http://www.reciclamais.com/pt/revista/edicoes-online Acesso em: 07 set. 2010

$\mathrm{Na}$ instalação, utilizar os mesmos tipos de parafusos usados em outras carcaças padrão de toner.

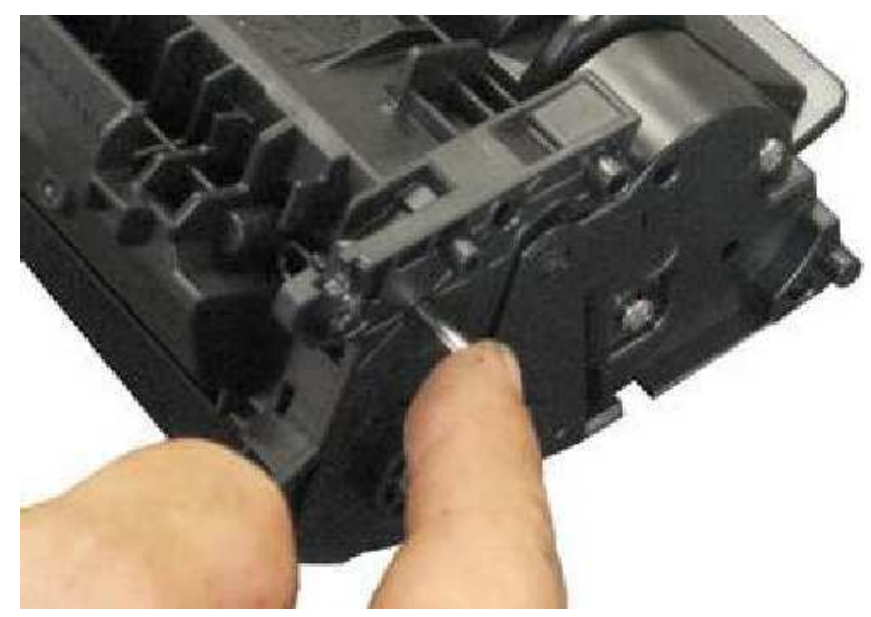

Figura 37: Colocação do pino.

Fonte: http://www.reciclamais.com/pt/revista/edicoes-online Acesso em: 07 set. 2010 

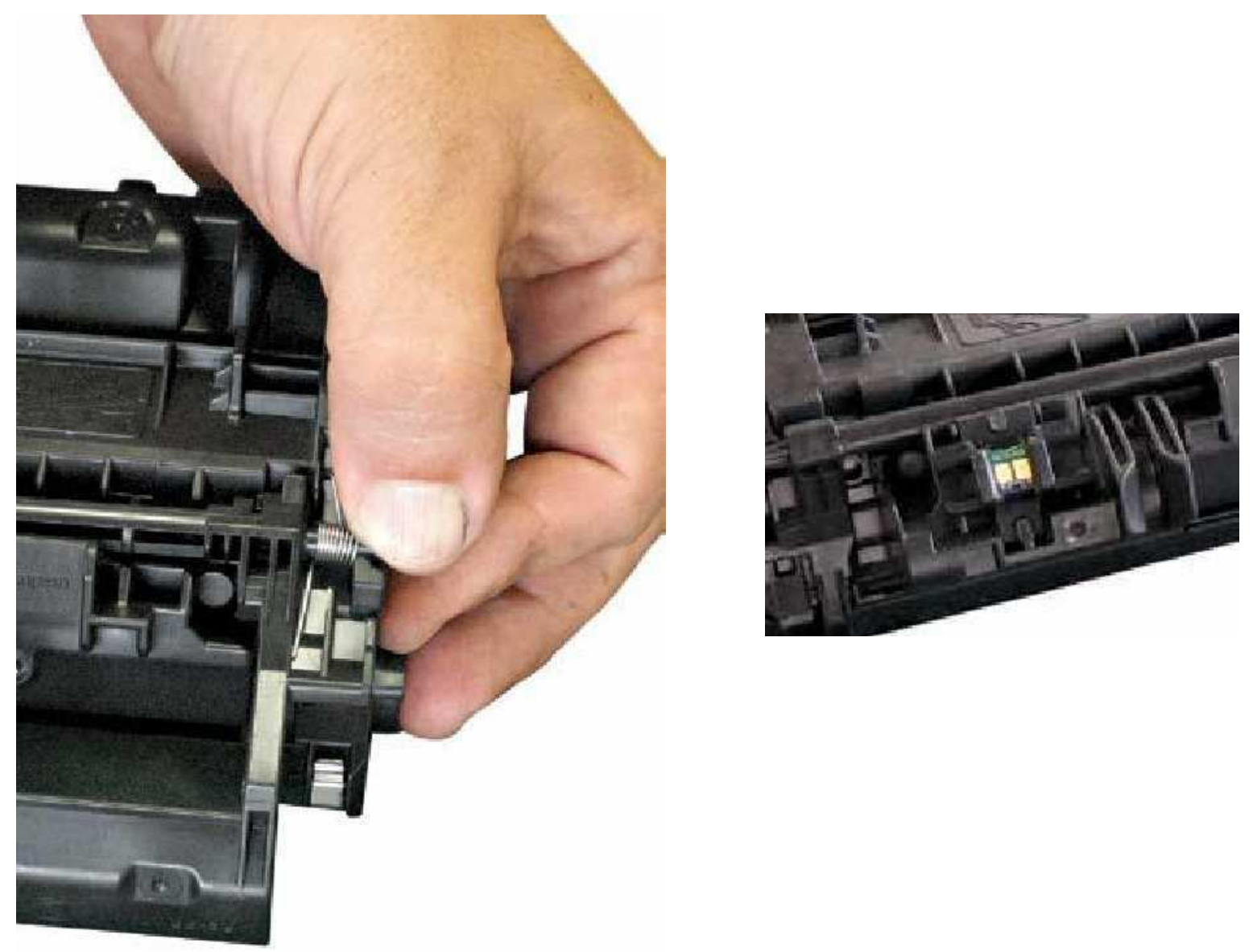

Figura 38: Posicionando a mola do obturador e Figura 39: Chip do cartucho. Fonte: http://www.reciclamais.com/pt/revista/edicoes-online

Acesso em: 07 set. 2010

Juntar as duas partes, colocando os pinos. Colocar o protetor de cilindro. Trocar o chip pelo chip específico para o modelo, respeitando o modelo "A" e "X". Testar o cartucho na impressora.

Finalmente, embalar o cartucho em um saco preto ou antiestática e colocá-lo em uma caixa de papelão apropriada.

\section{Solucionando os Principais Defeitos}

Podem ocorrer defeitos, tais como: vazamentos, riscos verticais na folha, falhas horizontais na folha, folha inteira branca e folha inteira preta. A seguir a solução para esses possíveis problemas:

- Vazamentos - este tipo de cartucho pode apresentar vazamentos por baixo das lâminas, especialmente na de dosagem. 
> Verificar a vedação abaixo das lâminas de limpeza e de dosagem;

$>$ Verificar os mancais do rolo magnético, possíveis pontos de vazamento se estiverem danificados;

> Verificar se a montagem da lâmina de dosagem está correta, com as linguetas das peças limpadoras em seus devidos lugares. A falta dessas linguetas acaba por não evitar vazamento pelas buchas ou pelo próprio rolo magnético.

- Riscos verticais na folha:

$>$ Finos, escuros: trocar o cilindro ótico;

$>$ Difusos, escuros: trocar a lâmina de limpeza;

Claros, grossos: trocar a lâmina de dosagem.

- Falhas horizontais na folha:

> Claras: cilindro magnético;

$>$ Escuras: PCR.

- Folha inteira branca:

$>$ Checar os contatos do cilindro magnético;

$>$ Checar os contatos do cilindro ótico.

- Folha inteira preta:

$>$ Checar os contatos do rolo de carga primária.

Podem acontecer ainda erros de chip e da impressora. No caso do erro "10.X", há problemas na impressora de comunicação com o chip no cartucho. Os principais motivos para esse erro são os seguintes:

Nenhum chip instalado;

A impressora não fez contato elétrico com o chip;

Um tipo errado de chip foi instalado;

Foi instalado um chip defeituoso e deve ser trocado.

Principais erros da impressora: 
13.XX - atolamento de papel;

21.XX - falha de impressão;

50.X - falha no fusor;

51.X - erro de scanner (para a série 2050);

52.X - erro de scanner (para a série 2030);

59.X - falha de motor principal.

Fonte: RECICLA MAIS: revista mensal eletrônica. São Paulo: Ed. Cecília Borges, n. 101, mai. 2010. Disponível em WWW:<URL:http://www.reciclamais.com/pt/revista/edicoesonline>. Acesso em: 07 set. 2010. 